\title{
Wet Atmospheric Deposition of Pesticides \\ in Minnesota, 1989-94
}

By Paul D. Capel, Ma Lin', and Paul J. Wotzka ${ }^{2}$

\section{U.S. Geological Survey}

Water-Resources Investigations Report 97-4026

Prepared in cooperation with the Minnesota Department of Agriculture

\section{Mounds View, Minnesota 1998}

\footnotetext{
${ }^{1}$ University of Minnesota, Department of Civil Engineering

${ }^{2}$ Minnesota Department of Agriculture, Agronomy Services Division
} 
U.S. DEPARTMENT OF THE INTERIOR

BRUCE BABBITT, Secretary

U.S. GEOLOGICAL SURVEY

Thomas J. Casadevall, Acting Director

For additional information write to:

Copies of this report can be purchased from:

District Chief

U.S. Geological Survey

2280 Woodale Drive

Mounds View, MN 55112
U.S. Geological Survey

Branch of Information Services

Box 25286

Denver, Colorado 80225-0286 


\section{Contents}

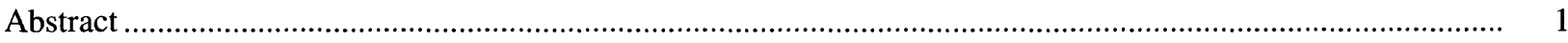

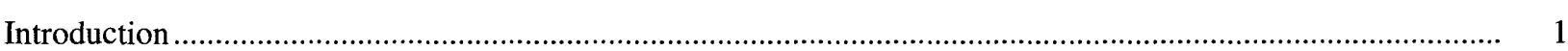

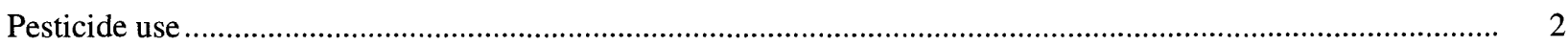

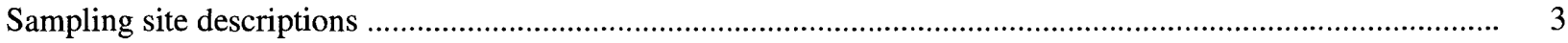

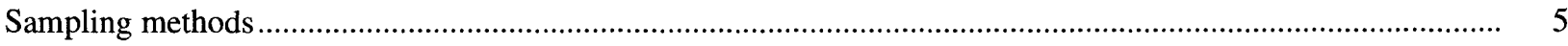

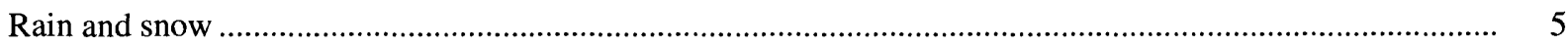

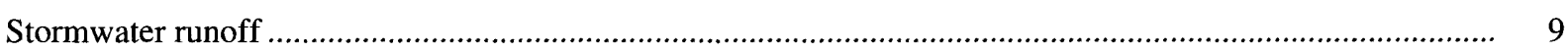

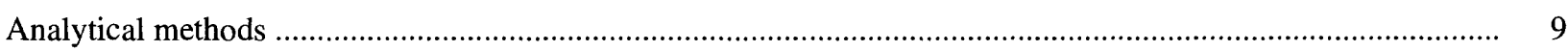

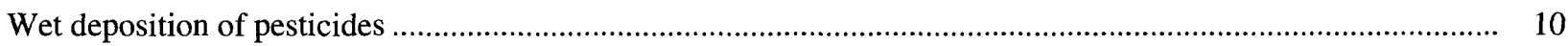

Annual summaries of detections and concentrations ........................................................................... 10

Seasonal patterns in detections, concentrations, and fluxes.................................................................. 16

Temporal and geographical distribution of fluxes in rain ................................................................... 18

Potential significance to surface-water quality ............................................................................... 22

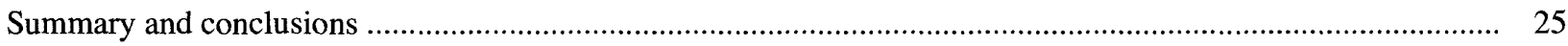

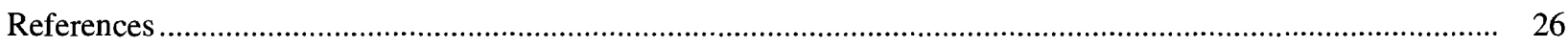

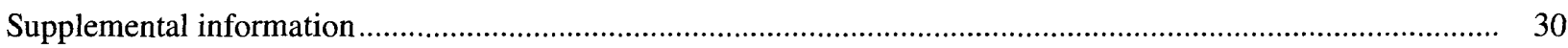

\section{Illustrations}

Figure 1. Graph showing agricultural use of selected herbicides in the United States and Minnesota, 1989,

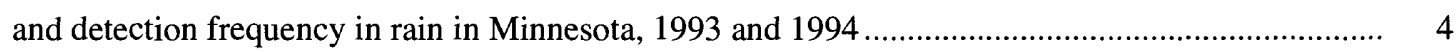

2. Map showing precipitation sampling sites in Minnesota .......................................................... 5

3. Graph showing years during which precipitation sampling sites were active ................................. 6

4-6. Schematics of:

4. Automatic precipitation collector for pesticides ................................................................... 7

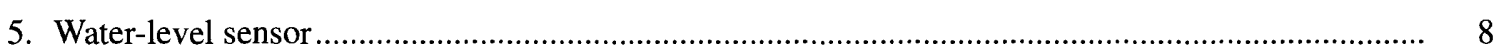

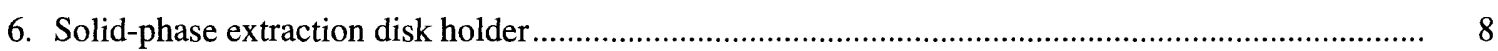

7-10. Graphs showing:

7. Frequency distributions of four herbicides in rain for all sites, 1991-94 ...................................... 15

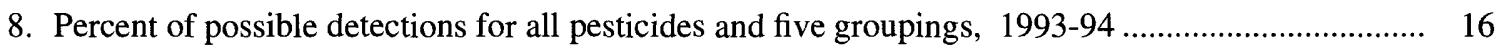

9. Concentrations of alachlor, atrazine, and cyanazine in rain or snow, in St. Paul and Rosemount, Minnesota 


\section{Illustrations-continued}

10. Flux of pesticides in rain at three sites during spring/early summer and late summer/fall, 1993 and 1994

11. Map of fluxes of pesticides in rain at six sites, 1993 and 1994

12-15. Graphs showing:

12. Fluxes of four high-use herbicides in rain at three sites, 1993 and 1994

13. Fluxes in river water and rain of four herbicides in three watersheds, 1993 and 1994

14. Cumulative flux of the sum of alachlor, atrazine, cyanazine, and metolachlor in stormwater runoff and rain in a small watershed that discharges to Lake Harriet, Minneapolis, Minnesota, during 1993

15. Concentrations and cumulative flux of alachlor in the Middle Branch of the Whitewater River and in rain near Crystal Springs, Minnesota, 1993

16. Schematic showing the circuit to control the pump from the water-level sensor in the rain sampler

\section{Tables}

Table 1. Summary of pesticides in rain at St. Paul, Minnesota, May through September 1989

2. Summary of pesticides in rain at Rosemount, Minnesota, May through July 1990

3. Summary of pesticides in rain at all sites, May through September 1991

4. Summary of pesticides in rain at all sites, May through September 1992.

5. Summary of pesticides in rain at all sites, May through September 1993

6. Summary of pesticides in rain at all sites, May through September 1994.

7. Total flux of all pesticides compared to the flux of cyanazine, 1993 and 1994

8. Sampling-site observers and their affiliation

9. Glossary of common and chemical names of the pesticides targeted in this study

10. Pesticides in rain near Crystal Springs, Minnesota, May through September 1993

11. Pesticides in rain near Lamberton, Minnesota, May through September 1993

12. Pesticides in rain, Minneapolis, Minnesota, April through September 1993

13. Pesticides in rain near Park Rapids, Minnesota, April through September 1993 


\section{Tables-continued}

14. Pesticides in rain near Princeton, Minnesota, May through September 1993 ................................... 37

15. Pesticides in rain near Blue Earth, Minnesota, May through September 1994 ................................. 38

16. Pesticides in rain near Crystal Springs, Minnesota, April through September 1994......................... 39

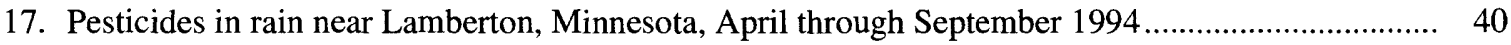

18. Pesticides in rain, Minneapolis, Minnesota, April through October 1994 ....................................... 41

19. Pesticides in rain near Park Rapids, Minnesota, April through September 1994 ............................. 42

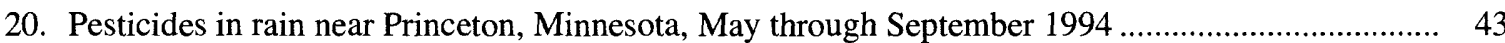

\section{Conversion Factors, Abbreviations, and Water-Quality Units}

$\begin{array}{lll}\text { Multiply } & \text { By } & \text { To Obtain } \\ \text { centimeter }(\mathrm{cm}) & 0.3937 & \text { inch } \\ \text { meter }(\mathrm{m}) & 3.281 & \text { foot } \\ \text { square meter }\left(\mathrm{m}^{2}\right) & 10.76 & \text { square foot } \\ \text { cubic meter }\left(\mathrm{m}^{3}\right) & 35.31 & \text { cubic foot } \\ \text { liter } & 0.2642 & \text { gallon } \\ \text { kilogram }(\mathrm{kg}) & 2.205 & \text { pound } \\ \text { degrees Celsius }\left({ }^{\circ} \mathrm{C}\right) & 1.8\left(\operatorname{temp~}^{\circ} \mathrm{F}-32^{\circ}\right) & \text { degrees Fahrenheit }\end{array}$

Chemical concentrations are given in metric units. Chemical concentrations of substances in water are given in milligrams per liter $(\mathrm{mg} / \mathrm{L})$ or micrograms per liter $(\mu \mathrm{g} / \mathrm{L})$. Milligrams per liter is a unit expressing the concentration of chemical constituents in solution as mass (milligrams) of solute per unit volume (liter) of water. One thousand micrograms per liter is equivalent to one milligram per liter. For concentrations less than $7,000 \mathrm{mg} / \mathrm{L}$, the numerical value is the same as for concentrations in parts per million.

Use of trade names in this report is for identification purposes only and does not constitute endorsement by the U.S. Geological Survey. 


\title{
Wet Atmospheric Deposition of Pesticides \\ in Minnesota, 1989-94
}

\author{
By Paul D. Capel, Ma Lin ${ }^{1}$, and Paul J. Wotzka²
}

\begin{abstract}
All of the rain samples during the growing season had detectable quantities of at least one pesticide, but most of the pesticides were only infrequently observed. The most frequently detected compounds were the herbicides alachlor, atrazine, cyanazine, and metolachlor, and in 1994, its first year of registration, acetochlor. Peak concentrations of most herbicides in rainfall occurred shortly after their application periods in the spring. Peak concentrations of most of the insecticides occurred later in the summer.

The majority of the wet depositional flux of pesticides occurred between early May and October. The annual wet depositional flux of pesticides is 5 orders of magnitude less than is the "annual flux" normally applied on an agricultural field, although some of the pesticides in rain are deposited in areas far removed from agricultural fields. The annual variability in pesticide deposition can be explained by year-to-year differences in climate and pesticide use patterns. The one sampling site (Lamberton) that was in an area dominated by row crop agriculture showed a significantly greater annual flux than the other four sampling sites that were in areas of either urbanization or less intensive agricultural. Regional deposition, away from a local source, can be inferred from these four sites because they have annual pesticide fluxes that are very similar for any given year. The observation of agricultural pesticides (not registered for home and garden use) in rain and storm runoff in the urban area indicates their transport from areas of agricultural use. Urban areas may be the best locations for assessing changes in regional use and deposition of agricultural pesticides.
\end{abstract}

The pesticide fluxes in the streams out of the small three watersheds was compared to the pesticide flux into the watersheds in rain. The data indicate that flux into the watersheds from the rain is generally much greater than the flux from the watersheds in the streams. Therefore, a large fraction of the pesticides deposited in rain is retained within the watersheds. For the urban area, this is on the order of 98 percent for the four most commonly observed herbicides in rain and runoff.

\footnotetext{
${ }^{1}$ University of Minnesota, Department of Civil Engineering

${ }^{2}$ Minnesota Department of Agriculture, Agronomy Services Division
}

\section{Introduction}

Concerns about the contamination of the atmosphere by organic chemicals have increased over the last four decades (Daines, 1952; Eisenreich and others, 1981a,b; Richards and others, 1987; Kurtz, 1990; Goolsby and others, 1993). Various pollutants, such as polychlorinated biphenyls (Eisenreich and others, 1981b; Strachan and Eisenreich, 1990; Chan and Perkins, 1989), polyaromatic hydrocarbons (Pankow and others, 1984; Ligocki and others, 1985a,b; Van Noort and Wondergem, 1985; Czuczwa and others, 1988; Leuenberger and others, 1988), phenols (Leuenberger and others,1985), and pesticides (Glotfelty and others, 1990; Brun and others, 1991; Goolsby and others, 1993) have been detected in atmospheric precipitation samples. A wide variety of pesticides have been measured in the atmosphere in air (Majewski and Capel, 1995), rain (Wu, 1981; Richards and others, 1987; Glotfelty and others, 1990; Capel, 1991; Nations and Hallberg, 1992; Goolsby and others, 1993), snow (Czuczwa and others, 1988; Welch and others, 1991) and fog (Glotfelty and others, 1987; Glotfelty and others, 1990; Capel and others, 1991; Schomburg and others, 1991; Valsaraj and others, 1993).

Since the 1960's, many of the studies of pesticides in the atmosphere have focused on organochlorine insecticides, even though many have been banned or their use greatly restricted in the United States. In the 1960 's and 1970's, air was the primary atmospheric matrix sampled and analyzed. The more environmentally persistent pesticides, such as DDT, 
$\mathrm{DDE}$, and $\alpha-\mathrm{HCH}$, were detected in the atmosphere at low levels throughout the year (Bidleman and others, 1987). Atmospheric transport distributes organochlorine pesticides on a global basis (Patton and others, 1989; Tatsukawa and others, 1990, Welch and others, 1991). Recently, research on wet deposition of pesticides has expanded to a number of nations, including the United States (Glotfelty and others, 1990; Goolsby and others, 1993), Canada (Brun and others, 1991; Welch and others, 1991), Switzerland (Buser, 1990), Germany (Scharf and others, 1992; Bester and others, 1995), and Japan (Haraguchi and others, 1995). In the United States, most of the focus of these recent studies has been the Midwest including Minnesota (Richards and others, 1987; Glotfelty and others, 1990; Capel, 1991; Nations and Hallberg, 1992; Goolsby and others,1993).

Atmospheric contamination by pesticides occurs mainly through their agricultural use. The physical and chemical properties of the pesticides play an important role in the introduction to, movement in, and deposition from the atmosphere. Pesticides enter the atmosphere during the application process (spray drift), through volatilization, and through wind erosion of soil particles to which the pesticides are sorbed (Majewski and Capel, 1995). In the atmosphere, the pesticides are redistributed among the vapor, particulate, and aqueous phases. This distribution among phases depends on their physical and chemical properties, such as vapor pressure and water solubility, and the temperature, presence of liquid water, and properties of particles (Tsal and Cohen, 1991). Pesticides that tend to associate with fine particles or exist predominantly in the vapor phase tend to have longer residence times in the atmosphere. These compounds can be transported to areas far from their application sites (Glotfelty and others, 1990; Goolsby and others, 1993). Pesticides are deposited through wet and dry removal of gases and particles from the atmosphere. The relative contribution of either process to total deposition depends on the amount and frequency of precipitation, the equilibrium air-water partition coefficient (Henry's Law constant), and the vapor-particle distribution in air (Bidleman, 1988).

One unintended aspect of pesticide use is the contamination of surface water. Surface water can receive pesticides through a variety of mechanisms, including field runoff, drainage of tiled fields, groundwater discharge, direct application, and atmospheric deposition (Squillace and others, 1993; Schlotter and others, 1992). For surface water that is remote from direct inputs of pesticides from agricultural or urban runoff, atmospheric deposition may be the major source of pesticides. Atmospheric deposition is considered to be the main source of the organochlorine insecticide in many remote areas (Eisenreich and others, 1981a,b; Patton and others, 1989; Welch and others, 1991). The atmosphere is now recognized as a major pathway by which pesticides, and other organic and inorganic compounds, are transported and deposited in areas that are often far removed from their sources (Majewski and Capel, 1995).

This report summarizes studies that have been conducted in Minnesota from 1989-94 on the wet deposition of current-use pesticides in rain and snow. (Studies from this time period on the deposition of organochlorine insecticides, compounds that have been banned from agricultural use, are not included in this report (Franz and others, 1991; Franz, 1994). The early, preliminary study of pesticides in rain and snow was conducted in 1989 and 1990 in St. Paul and Rosemount, Minnesota (Capel, 1991). Based on the findings of this study, a joint study among the U.S. Geological Survey (USGS), Minnesota Department of Agriculture (MDA), University of Minnesota (UM) and the Minneapolis Park and Recreation Board was undertaken to further examine pesticides in rain throughout the state. This report discusses the seasonal patterns in concentrations of pesticides in rain in Minnesota, compares pesticide concentrations and loads in urban and agricultural areas, and assesses the significance of wet deposition of pesticides with respect to surface-water contamination.

\section{Pesticide Use}

Pesticides have played a vital role in the production of food and fiber and in the protection of the health of humans. The use of herbicides to control weeds in crop production increased dramatically during the 1960's and 1970's. The use of agricultural herbicides in the United States increased 480 percent between 1964 (38 million $\mathrm{kg}$ active ingredient (AI) herbicides) and 1979 (221 million $\mathrm{kg}$ of AI herbicides). Since 1979, herbicide use has remained steady and insecticide use has decreased slightly. The annual total pesticide use after 1979 has remained relatively steady (Eichers and others, 1968; Gilliom and others, 1985; Aspelin, 1994).

About 500 million $\mathrm{kg}$ of AI pesticides are used each year in the United States in a wide variety of agricultural and nonagricultural settings. The total agricultural use of pesticides accounts for 75 percent of this total annual use (Aspelin, 1994). The use of herbicides accounts for 60 percent of the mass of pesticides used annually on cropland in the United States. In 1993, total agricultural use of herbicides was approximately 208 million $\mathrm{kg}$ AI 
per year. Use on corn (93 million $\mathrm{kg} \mathrm{AI}$ ) and soybeans ( 37 million $\mathrm{kg} \mathrm{AI}$ ) dominates the national totals accounting for about two-thirds of the mass of herbicides used. In 1989, atrazine, alachlor, metolachlor, EPTC, trifluralin, cyanazine, butylate, and pendimethalin were among the most commonly used herbicides nationally (fig. 1). These herbicides accounted for 63 percent of the total mass of herbicides used in United States crop production. National noncropland use of herbicides was estimated by the U.S. Environmental Protection Agency (USEPA) to be between 16 to 25 million $\mathrm{kg}$ AI per year (Aspelin, 1994). This is about 10 percent of total use of herbicides in the United States (Gianessi and Puffer, 1991).

Total annual use of herbicides in Minnesota was estimated at 13 million kg AI during 1990 (Kelly and Hines, 1990). Minnesota ranked third in the annual use of herbicides, after Iowa and Illinois. Use patterns in Minnesota are somewhat different than in the United States as a whole, such as the extremely high use of EPTC in Minnesota for 1989 (fig. 1). Total annual use of insecticides in Minnesota in 1990 was 0.67 million kg AI. Minnesota ranked 29th nationally in insecticide use (Gianessi and Puffer, 1992).

\section{Sampling Site Descriptions}

Rain sampling locations have varied during the years of this study, but together they cover various land use areas of Minnesota. Land use in Minnesota ranges from dense forests in the northeast to intensive row crops throughout the western and southern parts of the state. An intervening transition zone has mixed cropland, woodland, and pasture. Land use is affected by physiography, which varies from thin-soiled, crystalline bedrock in the northeastern area to the rich prairie soils in the till and outwash plains of southwestern Minnesota (Tornes, 1991). The sampling sites and their respective sampling years are shown in figures 2 and 3 . A brief description of each of the sampling sites follows.

The site near Blue Earth, in the south-central part of Minnesota, is in an area of intensive row-crop agriculture. The site is located in the East Fork of the Blue Earth River drainage basin. Rain was sampled in 1994. Surface water from the East Fork of the Blue Earth River was also sampled in 1994.

The site near Camp Ripley is located in the center of the state. It is in an area of forest with some cropland and pasture. It was sampled in 1991.

The site near Crystal Springs is located in the southeast part of the state. This area is cropland mixed with pasture and forest and is in the Whitewater River Basin. Rain was sampled from 1992 through 1994. Surface water from the Middle Branch of the Whitewater River was also sampled in 1993 and 1994.

The site near Ely is located in the Superior National Forest in the northeast part of Minnesota. This is an area of mostly forest. It was sampled in 1991.

The site in Icelandic State Park is just across the Minnesota state line, in extreme northeastern North Dakota, in an area of intensive row-crop agriculture. It was sampled in 1991 and 1992.

The site near Lamberton is located at the UM Agricultural Experimental Station in the southwest part of the State. This site is near the center of corn and soybean production, and is located within the Minnesota River Basin. It was sampled from 1991 through 1994.

The Minneapolis site is near Lake Harriet and is in an urban, residential area. Rain was sampled from 1992 through 1994. Stormwater from storm sewers draining into Lake Harriet was also sampled in 1993 and 1994.

The site near Marcell is located within the Chippewa National Forest in north-central Minnesota. It is in an area of forest and minor grazing and was sampled in 1991.

The site near Park Rapids is located in north-central Minnesota in an area of forest with some irrigated cropland and some pasture. It was sampled from 1992 through 1994.

The site near Princeton is located in east-central Minnesota at an agricultural research site in an area of cropland mixed with pasture and forest. It was sampled from 1991 to 1994.

The sampling site in Rosemount is located at the UM Agricultural Experimental Station in east-central Minnesota. It is in an area of cropland mixed with some pasture and forest. It was sampled in 1990 and 1991.

The site in St. Paul is in a residential area in the northwestern portion of the city. It was sampled in 1989.

The sites near Lamberton, Camp Ripley, Marcell, Ely, and Icelandic State Park were co-located at longterm precipitation sampling sites sponsored by the National Atmospheric Deposition Program (Roberts and Wojciechowski, 1986). 

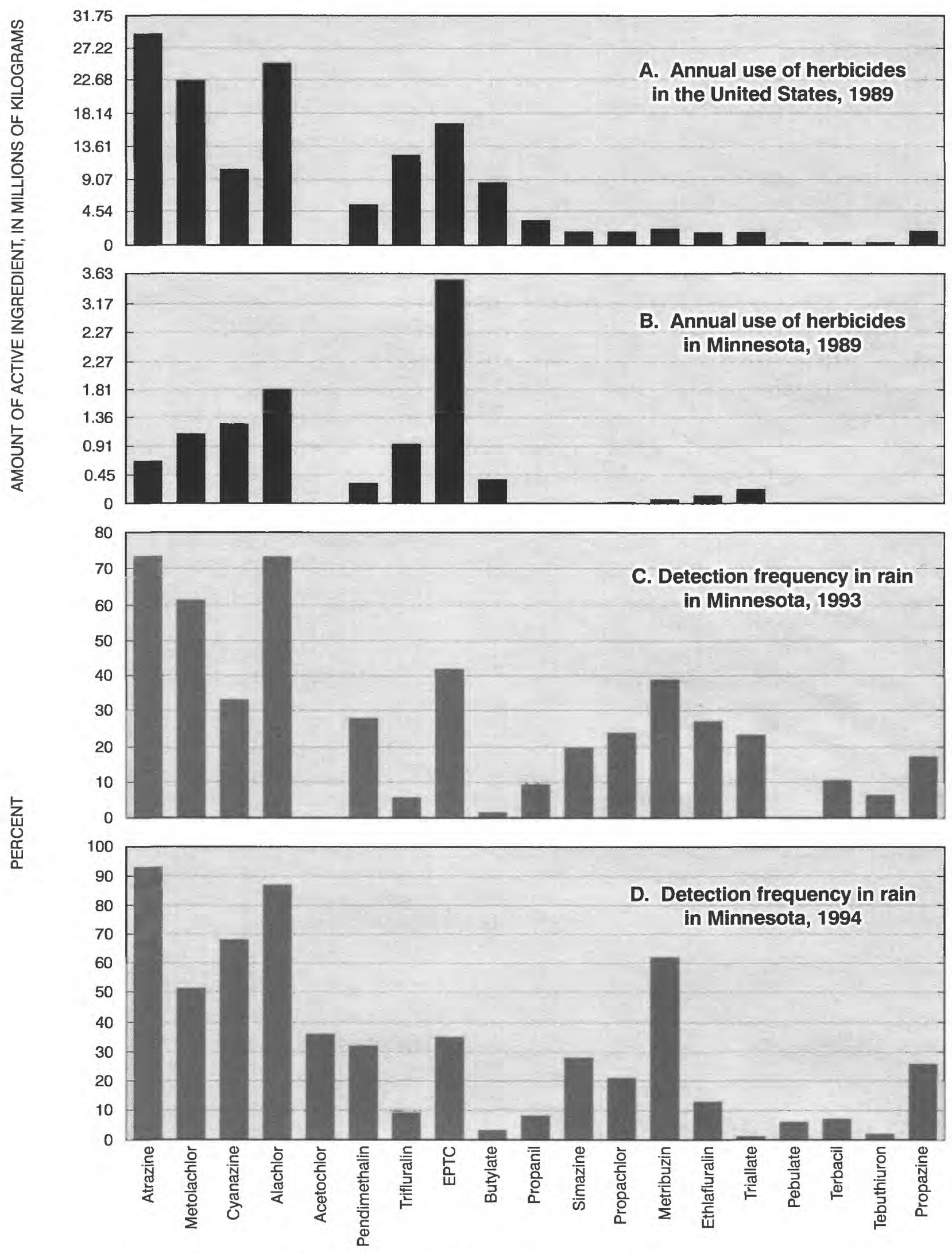

Figure 1. Agricultural use of selected herbicides in the United States and Minnesota, 1989, and detection frequency in rain in Minnesota, 1993 and 1994. (Data from Gianessi and Puffer (1991).) 


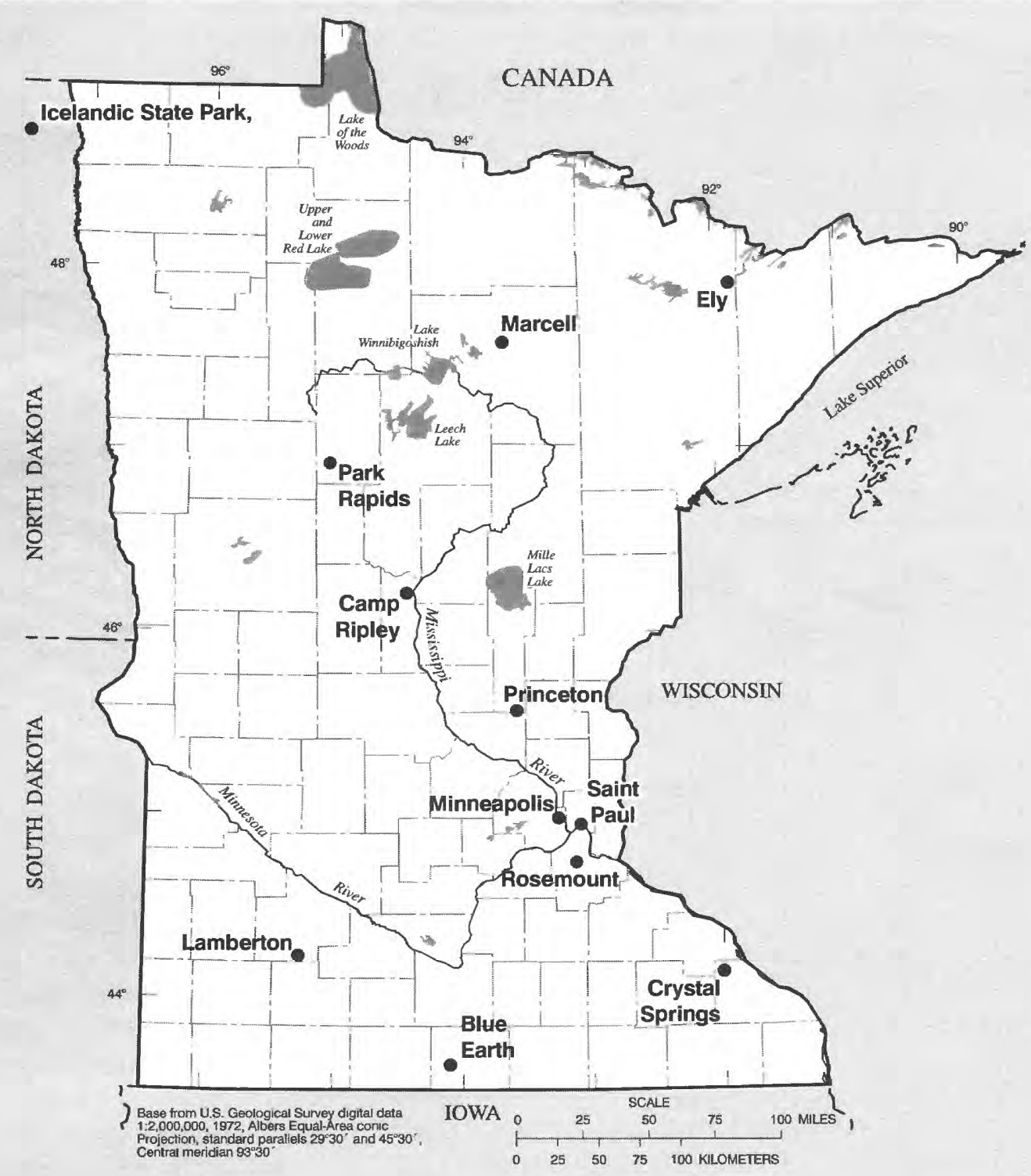

Figure 2. Precipitation sampling sites in Minnesota.

\section{Sampling Methods}

\section{Rain and Snow}

For 1991-94, precipitation samples for pesticide analyses were integrated for a period of one week and collected every Tuesday if the amount of precipitation was greater than $0.635 \mathrm{~cm}$ (more than 300 milliliters $(\mathrm{mL})$ ). Sampling occurred on a precipitation-event basis during March 1989 through June 1990. Based on results from these samples, the sampling period was shortened to include pre-plant (late April/early May) to harvest (late September/early October). The samples were obtained either by a local observer or by the study investigators (table 8, in the Supplemental Information section).

The precipitation collector (Aerochem Metrics Inc., Model 301) was a modified version of the collector that has been used by most of the major atmospheric deposition monitoring networks in the United States (fig. 4). It was chosen by the National Atmospheric Deposition Program (NADP) and the National Trends Network (NTN) of the National Acid Deposition Assessment Program (NADAP) for monitoring precipitation chemistry (National Atmospheric Deposition Program, 1988). Recently, they have 


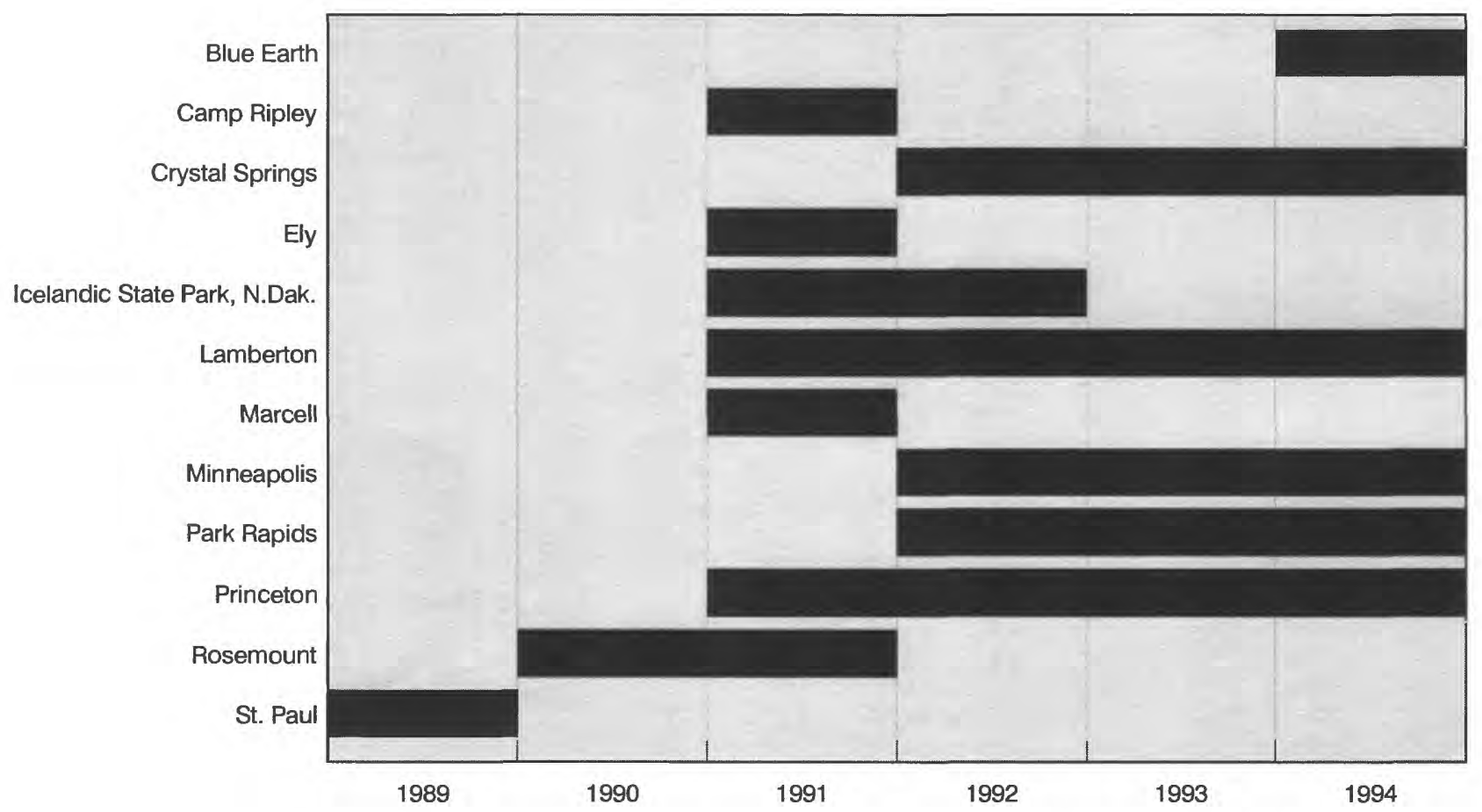

Figure 3. Years during which precipitation sampling sites were active.

been used to collect precipitation samples for herbicide analysis throughout the midwestern and northeastern United States (Goolsby and others, 1993).

The precipitation collector was equipped with two 13-liter (L) high-density, polyethylene buckets (diameter: $28.6 \mathrm{~cm}$, depth: $23.2 \mathrm{~cm}$, surface area: 640 $\mathrm{cm}^{2}$ ) that alternately collect wet or dry deposition. The "dry side" bucket is uncovered between precipitation events and, thus, collects only dry-deposited material. The "wet side" bucket is tightly covered with a movable lid until precipitation begins. When water droplets deposit on the electronic precipitation sensor, the sensing circuit activates a motor which removes the lid from the "wet side" to the "dry side" to collect a wet deposition sample. When precipitation ceases, the sensor closes the lid to the "wet side" bucket until the next precipitation event. The sensor base plate is heated during the wet cycle to increase the rate of evaporation and, hence, reduce the open time after the cessation of precipitation.

The precipitation collector was modified for this study to minimize the potential for sorption and contamination of pesticides by the plastic container, pesticide losses due to degradation, and the inconvenience of transportation of precipitation samples. The modifications to the precipitation collector were refined over time. During 1989 and 1991, a Teflon-lined, aluminum collection vessel with a Teflon outlet to drain the rain water to a 4-L glass bottle was used. Starting in 1992, the pesticides were isolated from the water in real-time by solid-phase extraction (SPE). The modifications to the precipitation sampler during this time period included a Teflon-lined aluminum collection vessel with a Teflon outlet tube, a glass water-level sensor, a pump, and an in-line solidphase extraction column (EnviroPrep, Baxter Corp., 50 milligram (mg) in 1992) or disk (Empore, 3M, diameter: 47 millimeter (mm) in 1993 and 1994) to provide the inplace filtration and extraction of pesticides from the water. The SPE holder was easily mailed to the laboratory.

In 1993 and 1994, the Teflon-lined, 6-L aluminum vessel (diameter: $25 \mathrm{~cm}$, depth: $15 \mathrm{~cm}$ ) was connected, through a Teflon tube, to the glass water-level sensor (fig. 5). The sensor was constructed with two pairs of platinum wire $3 \mathrm{~cm}$ apart embedded in a glass tube (diameter: $2.5 \mathrm{~cm}$, length: $12.5 \mathrm{~cm}$ ). The electrode sensed the water level and controlled the pump through an electronic control board (Supplemental Information section, fig. 16). When the water level reached the upper pair of platinum wires, indicating that 


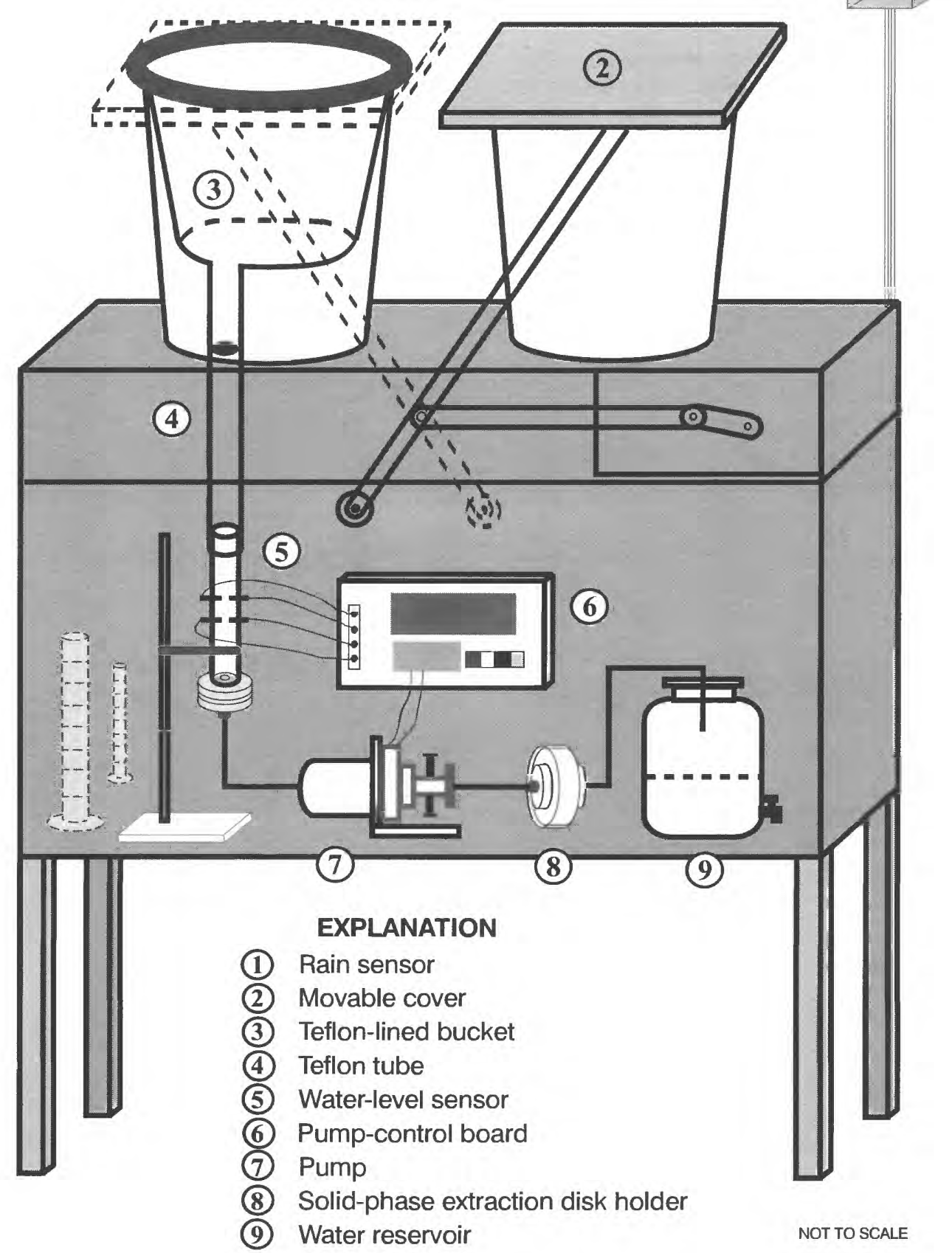

Figure 4. Schematic of automatic precipitation collector for pesticides. 
rain was being collected, the pump turned on. When the water level went below the lower pair of platinum wires, the pump turned off. This design protected the pump from turning on and off frequently during light precipitation. The inlet of the pump (FMI Lab, Model QSY, Fluid Metering, Inc.) was connected to the sensor through a Michael-Miller Teflon fitting (ACE Glass Inc.) and a $3.175 \mathrm{~mm}$ Teflon tube. The pump outlet was directed through $3.175 \mathrm{~mm}$ Teflon tubing to the SPE device. The rainwater was pumped at a rate of 15-20 milliliters per minute $(\mathrm{mL} / \mathrm{min})$ to an aluminum in-line filter holder that held a $47 \mathrm{~mm}$ glass-fiber filter (Whatman GF/F) and a C-18 SPE disk (Empore, 3M) that isolated the pesticides from the water (fig. 4). The aluminum filter holder (fig. 6) for the Empore disk was designed to reduce the residue of water within the holder. The rainwater that passed through the SPE disk holder was collected in a 6-L carboy waste container to measure the total volume of rainwater that was extracted.

The SPE device was changed every Tuesday, if there was rain during the week. Before replacing the SPE device, the Teflon-lined aluminum vessel, Teflon tube, glass sensor, and pump were rinsed with "organic-free" Milli-Q water (Millipore Corporation). SPE disks and glass fiber filters were cleaned and activated by

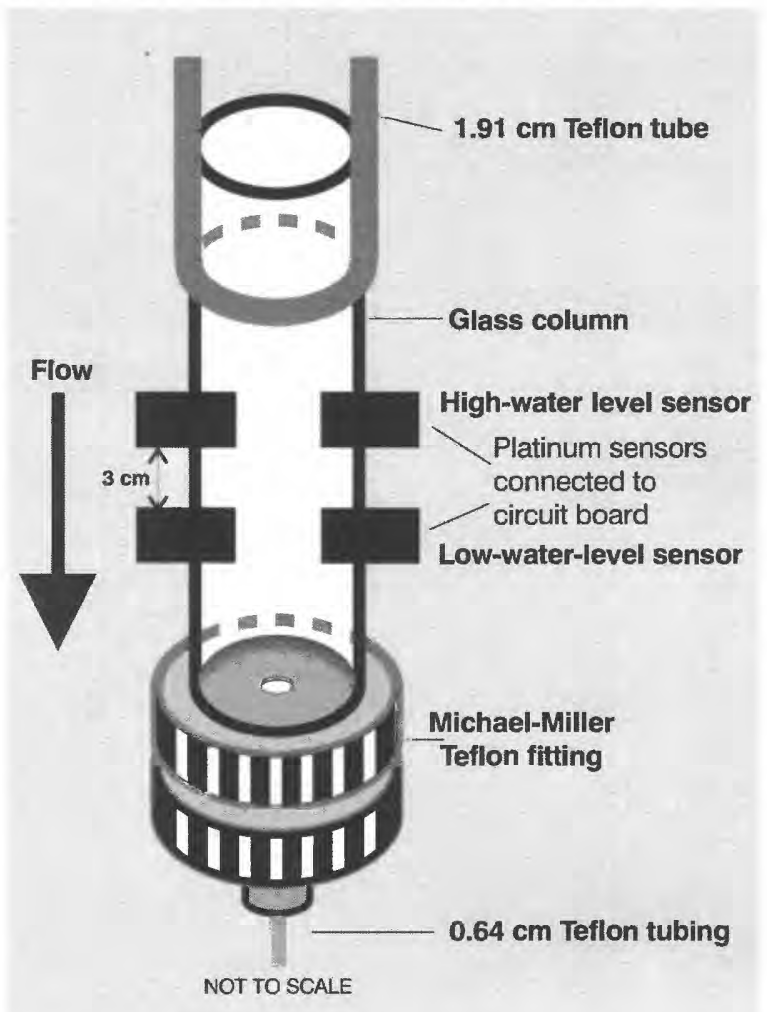

Figure 5. Schematic of water-level sensor.

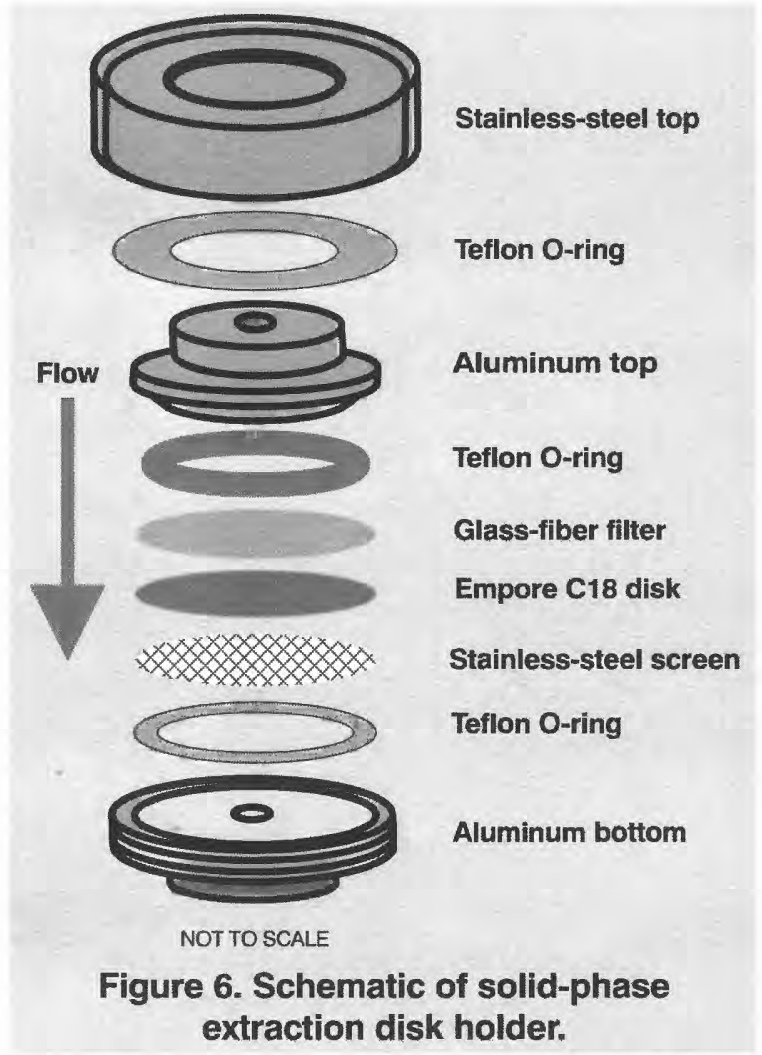

hexane/isopropyl alcohol (70 percent/30 percent, by volume), methyl alcohol, and Milli-Q water in sequence in the laboratory before they were deployed. This was done within the aluminum filter holder. The filter holders, still filled with water and sealed at both ends with Teflon plugs, were mailed to the sampling sites and deployed in the sampler.

A separate rain gauge was fixed on the side of the rain sampler to make the measurement of precipitation. It was located at the same height as the movable cover away from the precipitation sensor. A large metal box, holding the sensor, pump, electronics, SPE disk holder, Milli-Q water, and waste carboy, was located below the precipitation collector and locked to prevent damage or tampering (fig. 4).

During the winter of 1989-90, snow was collected on an event basis in St. Paul. The snow accumulated on a large, cleaned, Plexiglas sheet. It was removed with a cleaned, $10-\mathrm{cm}$ internal-diameter glass tube and a $20-\mathrm{cm}$ x 25-cm glass sheet and placed into a 4-L large-mouth, glass jar for storage. The volume of snow was determined by the depth of the snow and number of subsamples with the glass tube. The volume of melted snow was determined by mass. All concentrations of pesticides in snow presented here are on a snowmelt volume basis. 


\section{Stormwater Runoff}

Stormwater samples were collected near Lake Harriet in Minneapolis using an ISCO model 3700 automatic sampler fitted with cleaned glass bottles, Teflon tubing, and a stainless steel nozzle, and interfaced to an ISCO model 3220 flow meter with a submerged probe. The equipment was installed in a $1.37-\mathrm{m}$ diameter concrete storm sewer about $60 \mathrm{~m}$ upstream of Lake Harriet. Continuous flow measurements were taken at fiveminute intervals. The sampler collected stormwater based upon flow volumes recorded by the flow meter. A $250 \mathrm{~mL}$ water sample was collected for each $28 \mathrm{~m}^{3}$ of runoff water. The samples were composited and then refrigerated until they were analyzed. In 1992, 21 of 24 storm events (greater than $0.25 \mathrm{~cm}$ of rain) were sampled. In 1993, 20 of 43 storm events were sampled.

Stormwater samples in the Blue Earth and Whitewater Rivers were collected at automated monitoring stations equipped to monitor continuous rainfall, temperature and river stage data. During storm events, an ISCO model 3700 sampler was activated by a Campbell Scientific model CR10 datalogger when the river reached a predetermined stage. Samples were collected by the ISCO sampler into precleaned glass bottles at equal time increments for the duration of the storm runoff period. The samples were stored in ice during the collection period and then stored in a refrigerator after collection. Finally, samples were manually flow weighted by compositing an appropriate volume of each sample based on the streamflow represented by that sample as a percentage of the total streamflow over the entire storm event. The final composited sample was submitted to the Minnesota Department of Agriculture Laboratory Services for extraction and analysis.

\section{Analytical Methods}

The analytical methods were modified from 1989 to 1994. During this period, the number of target analytes increased from 4 to 35 (Supplemental Information section, table 9). Each of the analytical methods are briefly described below.

The 1989 and 1990 precipitation samples were collected in 4-L glass bottles. The pesticides were isolated from the water by SPE (C18, $5 \mathrm{mg})$ within one week. The SPE columns were centrifuged to remove the residual water. The pesticides were eluted from the SPE column with $4 \mathrm{~mL}$ of diethyl ether. The extracts were passed through about $6 \mathrm{~cm}$ of anhydrous sodium sulfate and collected in a glass centrifuge tube. The volume of diethyl ether was reduced by a gentle stream of nitrogen and the solvent was switched to hexane. The extract was analyzed by gas chromatography with a mass selective detector in selective ion monitoring mode. The target analytes were atrazine, alachlor, and cyanazine.

The 1991 and 1992 rain samples and the 1993 and 1994 stormwater samples were analyzed by the MDA's Laboratory Service Division. In 1991, the method employed liquid/liquid extraction of the rain samples with methylene chloride, concentration of extract, and a solvent switch to hexane. The extract was analyzed by gas chromatography with various specific detectors. In 1992, the pesticides were isolated from the rain samples with SPE in the field. The SPE columns were centrifuged to remove the residual water. The pesticides were eluted from the SPE column with $4 \mathrm{~mL}$ of diethyl ether. The extracts were passed through about $6 \mathrm{~cm}$ of anhydrous sodium sulfate and collected in a glass centrifuge tube. The volume of diethyl ether was reduced by a gentle stream of nitrogen in a $45^{\circ} \mathrm{C}$ water bath and the solvent was switched to hexane. The extract was analyzed by gas chromatography with various specific detectors. All positive detections were confirmed by gas chromatography/mass spectrometry in the selective ion mode. The 1993 and 1994 stormwater samples were analyzed by this same method.

In 1993 and 1994, the analyses of pesticides in rain samples were performed at the University of Minnesota. To eliminate contamination, all glassware was cleaned with Liquinox detergent, rinsed with tap water, then Milli-Q water (Millipore Corporation), and baked at $550^{\circ} \mathrm{C}$ for 6 hours in a temperature-programmable muffle furnace (Paragon Electric Kiln, DTC 600). Glass filters (Whatman GF/F, 4.7-cm internal diameter (ID)), glass wool, and granular sodium sulfate were heated at $550^{\circ} \mathrm{C}$ for 6 hours and stored in Pyrex glass beakers in an oven at $110^{\circ} \mathrm{C}$. Precise measuring glassware such as volumetric flasks, volumetric pipettes, and other laboratory items such as forceps, spatulas, and filtration devices, which could not be baked, were rinsed with methanol or acetone, hexane, and diethyl ether. The cleaned items were allowed to air-dry in the fume hood, then placed in an oven at $110^{\circ} \mathrm{C}$ for one hour.

Autosampler vial inserts were rinsed with methanol, hexane, and diethyl ether three times each in sequence and stored in a covered beaker. All cleaned items were wrapped or covered with aluminum foil. Organic-free Milli-Q water was used for blanks, recovery studies, and activating the SPE disks. All were pesticide residuegrade solvents (Burdick and Jackson). Surrogate compounds (terbuthylazine and butachlor) used for standard solutions were "Pestanal" reagents obtained from Crescent Chemical Company. The internal 
standard compounds (d-10 anthracene and 4,4-dibromobiphenyl) were purchased from Supelco, Inc. Standard stock solutions came from either the MDA laboratory or the USGS National Water Quality Laboratory (Zaugg and others, 1995). These solutions were further diluted to obtain a series of working standard solutions for calibration curves.

Before being deployed in the field, the SPE disk was washed sequentially with $5 \mathrm{~mL}$ of hexane/isopropyl alcohol ( 70 percent $/ 30$ percent, by volume), $5 \mathrm{~mL}$ of methanol, and $10 \mathrm{~mL}$ of Milli-Q water. The SPE disk holder was shipped to the sampling site and deployed. After the filter holder with the used SPE disk was received in the laboratory, it was dried by vacuum, then eluted with $15-20 \mathrm{~mL}$ of 30 percent isopropyl alcohol in hexane in three aliquots. Surrogates (terbuthylazine and butachlor) were spiked into the eluate to quantify the analytical efficiency. The eluate was passed through an anhydrous sodium sulfate column to remove trace residual water. The solvent was evaporated to $100-150$ microliters $(\mu \mathrm{L})$ using an evaporation apparatus (Supelco 6-port Mini-Vap) and quantitatively transferred to an autosampler vial. Internal standards were added before it was tightly capped. Final analysis was performed by gas chromatography/mass spectrometry in the selected ion monitoring acquisition mode (HP 5890GC, Hewlett Packard). The analytical column for gas chromatography was a J\&W DB-5 column, $30 \mathrm{~m} \times 0.25 \mathrm{~mm}$ ID, with a film thickness of $0.25 \mathrm{~mm}$. The temperature program was $100^{\circ} \mathrm{C}$ for 5 minutes (min), increased at $6^{\circ} \mathrm{C} / \mathrm{min}$ to $300^{\circ} \mathrm{C}$ and held at that temperature for $5 \mathrm{~min}$. Injector and detector temperature were $250^{\circ} \mathrm{C}$ and $285^{\circ} \mathrm{C}$, respectively. The flow rate of carrier gas, helium, was set at $0.9 \mathrm{~mL} / \mathrm{min}$.

All target analytes were quantified by comparing retention times, mass spectra, and ion intensities with those observed using standards. For most of the sample analyses, the recoveries of surrogate standard compounds varied from 70 to 120 percent. The reported concentrations of pesticides have not been adjusted to 100-percent recovery. The recoveries of terbuthylazine and butachlor are good indicators for the triazine and acetanilide herbicide recoveries, respectively. The method detection limits were determined by measuring a series of standard solution dilutions. For a $500 \mathrm{~mL}$ sample, the detection limits for all target pesticides were $0.01 \mu \mathrm{g} / \mathrm{L}$, except for cyanazine, terbacil, lindane, methyl parathion, malathion and azinphos methyl which were $0.02 \mu \mathrm{g} / \mathrm{L}$. Because the volumes of the rain samples varied appreciably, it was impossible to establish a consistent detection limit.

\section{Wet Deposition of Pesticides}

The results of 1989-94 are summarized in tables 1-6. The summary tables include the common and brand name of each target analyte, the percent of detections from all rain samples at all sites, the maximum observed concentration, and the date and location of the maximum observed concentration. The target analytes are grouped according to class: herbicides, insecticides, fungicides and degradation products; and within each class they are ranked in the order of decreasing percent detections. For pesticides that were never detected above the method detection limit, the value of the method detection limit (assuming rain sample volume of $500 \mathrm{~mL}$ ) is preceded by a less than symbol in the column for maximum observed detection. The Supplemental Information section presents a summary for each of the sampling sites from 1993 and 1994, including the common and brand names, the percent of detections, and the observed maximum and median concentrations (tables 10-20, in the Supplemental Information section).

Throughout this discussion it must be remembered that 1993 had an abnormally wet late spring and summer in Minnesota. This caused many rivers to flood and set many streamflow discharge records throughout Minnesota and much of the midwestern United States.

\section{Annual Summaries of Detections and Concentrations}

This study has changed over six years in an attempt to better collect rain samples and to better quantify a wider variety of pesticides at lower concentrations. As can be observed from tables 1-6, the changes in the study have resulted in a greater number of compounds being

Table 1.-Summary of pesticides in rain at St. Paul, Minnesota, May through September 1989.

[Total number of samples is 21 , analyzed at the University of Minnesota; $\mu \mathrm{g} / \mathrm{L}$, micrograms per liter]

\begin{tabular}{lcccc}
\hline Common name & Brand name & $\begin{array}{c}\text { Percent } \\
\text { detection }\end{array}$ & $\begin{array}{c}\text { Maximum } \\
\text { concentration } \\
(\mu \mathrm{g} / \mathrm{L})\end{array}$ & $\begin{array}{c}\text { Date of maximum } \\
\text { concentration }\end{array}$ \\
\hline Atrazine & Aatrex & 81 & 1.6 & May 23 \\
Alachlor & Lasso & 67 & 1.3 & May 29 \\
Cyanazine & Bladex & 52 & 3.8 & May 23 \\
\hline
\end{tabular}


detected and more frequent detections of some compounds. As an example (fig. 7), the frequency of detection of alachlor, atrazine, cyanazine, and metolachlor in rain increased in 1993 and 1994 as compared to 1991 and 1992 due to the lower detection limits in the later two years. Sample frequency distributions over the four year period were similar for concentrations greater than $0.5 \mu \mathrm{g} / \mathrm{L}$ (fig. 7). Because 1993 and 1994 are the most complete data sets, most of the following discussion will be based on these years. Of the 30 pesticides that were targeted for analysis in 1993, 24 were detected at least once. In 1994, 29 out of
32 targeted pesticides were detected. The more limited results of 1989-92 agree with the results of these later two years.

The pesticides targeted in this study have been divided into five groups for purposes of this evaluation. These groups include:

(1) triazine herbicides (atrazine, cyanazine, metribuzin, propazine, and simazine).

(2) acetanilide herbicides (acetochlor, alachlor, metolachlor, and propachlor).

Table 2.-Summary of pesticides in rain at Rosemount, Minnesota, May through July 1990. [Total number of samples is 12 , analyzed at the University of Minnesota; $\mu \mathrm{g} / \mathrm{L}$, micrograms per liter]

\begin{tabular}{lcclcc}
\hline Common name & Brand name & $\begin{array}{c}\text { Percent } \\
\text { detection }\end{array}$ & $\begin{array}{c}\text { Maximum } \\
\text { concentration } \\
(\mu \mathrm{g} / \mathrm{L})\end{array}$ & $\begin{array}{c}\text { Date of maximum } \\
\text { concentration }\end{array}$ \\
\hline Atrazine & Aatrex & 100 & .7 & May 7 \\
Alachlor & Lasso & 100 & 22 & June 1 \\
Cyanazine & Bladex & 41 & 2.7 & May 7 \\
\hline
\end{tabular}

Table 3.-Summary of pesticides in rain at all sites, May through September 1991.

[Total number of samples is 106 from 7 sites (Icelandic State Park, Ely, Marcell, Camp Ripley, Princeton, Rosemount, and Lamberton) Laboratory analysis conducted by Dee Mueller and Gary Horvath, Laboratory Services Division, Minnesota Department of Agriculture; $\mu \mathrm{g} / \mathrm{L}$, micrograms per liter; --, not determined]

\begin{tabular}{|c|c|c|c|c|c|}
\hline Common name & Brand name & $\begin{array}{l}\text { Percent } \\
\text { detection }\end{array}$ & $\begin{array}{l}\text { Maximum } \\
\text { concentration } \\
(\mu \mathrm{g} / \mathrm{L})\end{array}$ & $\begin{array}{l}\text { Date of maximum } \\
\text { concentration }\end{array}$ & $\begin{array}{l}\text { Site of maximum } \\
\text { concentration }\end{array}$ \\
\hline \multicolumn{6}{|c|}{ Herbicides } \\
\hline Alachlor & Lasso & 15 & 3.6 & May 21 & Rosemount \\
\hline Cyanazine & Bladex & 3 & 1.5 & May 28 & Lamberton \\
\hline Atrazine & Aatrex & 2 & .82 & July 2 & Rosemount \\
\hline Ethalfluralin & Sonalan & 0 & $<.20$ & -- & -- \\
\hline Metolachlor & Dual & 0 & $<.10$ & -- & -- \\
\hline Metribuzin & Sencor & 0 & $<.20$ & -- & -- \\
\hline Pendimethalin & Prowl & 0 & $<.10$ & -- & -- \\
\hline Prometon & Pramitol & 0 & $<.10$ & -- & -- \\
\hline Propachlor & Ramrod & 0 & $<.25$ & -- & -- \\
\hline Propazine & Milogard & 0 & $<.25$ & -- & -- \\
\hline Trifluralin & Treflan & 0 & $<.10$ & -- & -- \\
\hline \multicolumn{6}{|c|}{ Insecticides } \\
\hline Fonofos & Dyfonate & 0 & $<.12$ & -- & -- \\
\hline Lindane & Lindane & 0 & $<.03$ & -- & -- \\
\hline Terbufos & Counter & 0 & $<.15$ & - & -- \\
\hline \multicolumn{6}{|c|}{ Fungicide } \\
\hline Chlorothalonil & Bravo & 0 & $<.09$ & -- & -- \\
\hline
\end{tabular}


(3) soil-incorporated herbicides (benfluralin, butylate, EPTC, ethalfluralin, pendimethalin, and trifluralin).

(4) "other" herbicides—compounds that generally have low agricultural use in Minnesota (pebulate, prometon, propanil, tebuthiuron, terbacil, and triallate), although triallate does have a significant use in northwestern Minnesota.

(5) insecticides (see table 6 for list).

The percent of detections is graphed by group in figure 8 for both 1993 and 1994. The percent of detections among the various groups was similar between the two years. By far, the two highest percentages were the triazine and acetanilide herbicides. These compounds generally are applied to the soil surface as pre-emergent herbicides. This mode of application appears to make them readily available to move from the soil into the atmosphere (either through volatilization or wind erosion) and eventually removed by rain. The group of soil-incorporated herbicides had a substantially lower frequency of detection. These compounds are generally quite volatile, so they are applied within the soil. The soil then acts as a physical barrier to their loss to the atmosphere. The group of "other" herbicides were detected quite infrequently, most likely a result of infrequent use in the study area. The insecticides, as a class, are less frequently detected than the herbicides. This difference is probably due to less use, use later in the growing season when rains are less frequent, and in general, shorter persistence in the environment.

The frequency of detections varied greatly among the pesticides targeted in this study. The most frequently detected compounds in 1994 were atrazine, alachlor, cyanazine, metribuzin, and metolachlor (table 6). The

Table 4.- Summary of pesticides in rain at all sites, May through September 1992

[Total number of samples is 71 from 6 sites (Icelandic State park, Park Rapids, Princeton, Minneapolis, Crystal Springs, and Lamberton) Laboratory analysis conducted by Dee Mueller and Gary Horvath, Laboratory Services Division, Minnesota Department of Agriculture; $\mu \mathrm{g} / \mathrm{L}$, micrograms per liter; --, not determined]

\begin{tabular}{|c|c|c|c|c|c|}
\hline Common name & Brand name & $\begin{array}{c}\text { Percent } \\
\text { detection }\end{array}$ & $\begin{array}{l}\text { Maximum } \\
\text { concentration } \\
(\mu \mathrm{g} / \mathrm{L})\end{array}$ & $\begin{array}{l}\text { Date of maximum } \\
\text { concentration }\end{array}$ & $\begin{array}{l}\text { Site of maximum } \\
\text { concentration }\end{array}$ \\
\hline \multicolumn{6}{|c|}{ Herbicides } \\
\hline Atrazine & Aatrex & 18 & 2.2 & May 26 & Lamberton \\
\hline Alachlor & Lasso & 16 & 2.0 & May 26 & Lamberton \\
\hline Cyanazine & Bladex & 9 & 4.4 & May 26 & Lamberton \\
\hline Metolachlor & Dual & 9 & .05 & May 26 & Lamberton \\
\hline EPTC & Eradicane & 1 & .10 & May 19 & Crystal Springs \\
\hline Ethalfluralin & Sonalan & 0 & $<.20$ & -- & -- \\
\hline Metribuzin & Sencor & 0 & $<.20$ & -- & -- \\
\hline Pendimethalin & Prowl & 0 & $<.10$ & -- & -- \\
\hline Prometon & Pramitol & 0 & $<.20$ & -- & -- \\
\hline Propachlor & Ramrod & 0 & $<.25$ & -- & -- \\
\hline Propazine & Milogard & 0 & $<.25$ & -- & -- \\
\hline Trifluralin & Treflan & 0 & $<.10$ & -- & -- \\
\hline \multicolumn{6}{|c|}{ Insecticides } \\
\hline Chlorpyrifos & Lorsban & 0 & $<.05$ & -- & -- \\
\hline Diazinon & Diazinon & 0 & $<.12$ & -- & -- \\
\hline Fonofos & Dyfonate & 0 & $<.12$ & -- & -- \\
\hline Methyl parathion & Penncap-M & 0 & $<.10$ & -- & -- \\
\hline Phorate & Thimet & 0 & $<.25$ & -- & -- \\
\hline Terbufos & Counter & 0 & $<.15$ & -- & -- \\
\hline \multicolumn{6}{|c|}{ Herbicide degradation products } \\
\hline Deethyl atrazine & & 0 & $<.50$ & -- & -- \\
\hline Deisopropyl atrazine & & 0 & $<.50$ & -- & -- \\
\hline
\end{tabular}


results for 1993 were similar (table 5). Some compounds were never or seldom detected (benfluralin diazinon, pebulate, and so forth, tables 5 and 6). The frequency of detection of the various pesticides is partly a function of the agricultural management practices used during their application. One way to illustrate this is to calculate the percent of the total possible number of times that pesticides, grouped by management practices, were measured in rain. As an example (fig. 8), the soilinc,orporated herbicides (benfluralin, butylate, EPTC, ethalfluralin, pendimethalin, and trifluralin) were measured 98 times in 107 samples (642 possible detections) in 1994. This is an overall detection rate of 15.3 percent of possible detections.

The percent detections for 19 herbicides from all sites in 1993 and 1994 are plotted in comparison with their estimated use in the United States and in Minnesota (fig. 1). Some of the most frequently detected pesticides in rain were the surface-applied, pre-emergent herbicides: atrazine, alachlor, cyanazine, and metachlor.

Table 5.-Summary of pesticides in rain at all sites, May through September 1993.

[Total number of samples is 77 from 5 sites (Park Rapids, Princeton, Minneapolis, Crystal Springs, and Lamberton) Laboratory analysis conducted at the University of Minnesota; $\mu \mathrm{g} / \mathrm{L}$, micrograms per liter; --, not determined]

\begin{tabular}{|c|c|c|c|c|c|}
\hline Common name & Brand name & $\begin{array}{c}\text { Percent } \\
\text { detection }\end{array}$ & $\begin{array}{c}\text { Maximum } \\
\text { concentration } \\
(\mu \mathrm{g} / \mathrm{L})\end{array}$ & $\begin{array}{l}\text { Date of maximum } \\
\text { concentration }\end{array}$ & $\begin{array}{l}\text { Site of maximum } \\
\text { concentration }\end{array}$ \\
\hline \multicolumn{6}{|c|}{ Herbicides } \\
\hline Alachlor & Lasso & 74 & 12 & May 25 & Lamberton \\
\hline Atrazine & Aatrex & 71 & 2.9 & June 25 & Princeton \\
\hline Metolachlor & Dual & 61 & .92 & June 8 & Lamberton \\
\hline Metribuzin & Sencor & 39 & .05 & July 13 & Lamb./Park R. \\
\hline EPTC & Eradicane & 35 & 1.4 & May 25 & Lamberton \\
\hline Cyanazine & Bladex & 30 & 3.5 & June 15 & Lamberton \\
\hline Ethalfluralin & Sonalan & 29 & .08 & June 25 & Princeton \\
\hline Pendimethalin & Prowl & 27 & 1.4 & June 8 & Lamberton \\
\hline Triallate & Far-Go & 25 & .26 & July 13 & Lamberton \\
\hline Propachlor & Ramrod & 23 & .32 & May 25 & Minneapolis \\
\hline Simazine & Princep & 21 & 1.3 & June 15 & Princeton \\
\hline Propazine & Milogard & 18 & .06 & June 15 & Princeton \\
\hline Terbacil & Sinbar & 10 & 1.4 & May 18 & Lamberton \\
\hline Propanil & Erban & 9 & .11 & August 24 & Park Rapids \\
\hline Tebuthiuron & Spike & 5 & .03 & September 14 & Park Rapids \\
\hline Trifluralin & Treflan & 5 & 0 & June 15 & Lamberton \\
\hline Prometon & Pramitol & 3 & .02 & August 24 & Lamb./Park R. \\
\hline Butylate & Sutan+ & 1 & .03 & June 8 & Lamberton \\
\hline Benfluralin & Benefin & 0 & $<.01$ & -- & -- \\
\hline Pebulate & Tillam & 0 & $<.01$ & -- & -- \\
\hline \multicolumn{6}{|c|}{ Insecticides } \\
\hline Methyl parathion & Penncap-M & 40 & .15 & June 15 & Princeton \\
\hline Chlorpyrifos & Lorsban & 19 & .08 & June 8 & Lamberton \\
\hline Terbufos & Counter & 14 & .29 & June 22 & Park Rapids \\
\hline Malathion & Cythion & 6 & .10 & July 29 & Princeton \\
\hline Ethoprop & Mocap & 5 & .03 & June 16 & Crystal Springs \\
\hline Phorate & Thimet & 1 & .01 & July 13 & Lamberton \\
\hline Diazinon & Diazinon & 0 & $<.01$ & -- & -- \\
\hline Lindane & Lindane & 0 & $<.02$ & -- & -- \\
\hline Azinphos-methyl & Guthion & 0 & $<.02$ & -- & -- \\
\hline Permethrin & Ambush & 0 & $<.01$ & -- & -- \\
\hline
\end{tabular}


These are the same pesticides that are most frequently detected in Minnesota's rivers and streams (Larson and others, 1995; Schottler and others, 1992). Some of the other commonly used herbicides, such as EPTC, trifluralin and butylate, were not as frequently detected in the rain probably because they are incorporated into the soil and generally have shorter soil half-lives (University of Minnesota, 1992). Some other pesticides, such as metribuzin, pendimethalin, ethalfluralin, and propachlor were detected frequently but at consistently low concentrations (fig. 1 and table 5).

Acetochlor was detected at all sites in 1994 at similar concentrations and detection frequencies as other commonly used herbicides (table 6 and tables 15-20 in the Supplemental Information section). The detections

Table 6.-Summary of pesticides in rain at all sites, May through September 1994.

[Total number of samples is 107 from 6 sites (Park Rapids, Princeton, Minneapolis, Crystal Springs, Blue Earth, and Lamberton) Laboratory analysis conducted at the University of Minnesota; $\mu \mathrm{g} / \mathrm{L}$, micrograms per liter; --, not determined]

\begin{tabular}{|c|c|c|c|c|c|}
\hline Common name & Brand name & $\begin{array}{l}\text { Percent } \\
\text { detection }\end{array}$ & $\begin{array}{l}\text { Maximum } \\
\text { concentration } \\
(\mu \mathrm{g} / \mathrm{L})\end{array}$ & $\begin{array}{l}\text { Date of maximum } \\
\text { concentration }\end{array}$ & $\begin{array}{l}\text { Site of maximum } \\
\text { concentration }\end{array}$ \\
\hline \multicolumn{6}{|c|}{ Herbicides } \\
\hline Atrazine & Aatrex & 93 & 2.8 & June 7 & Lamberton \\
\hline Alachlor & Lasso & 87 & 1.2 & May 24 & Princeton \\
\hline Cyanazine & Bladex & 68 & 24 & May 24 & Princeton \\
\hline Metribuzin & Sencor & 62 & 1.1 & June 14 & Minneapolis \\
\hline Metolachlor & Dual & 51 & .70 & June 7 & Lamberton \\
\hline Acetochlor & Harness+ & 36 & .46 & April 26 & Crystal Springs \\
\hline EPTC & Eradicane & 35 & .26 & August 2 & Princeton \\
\hline Pendimethalin & Prowl & 32 & .43 & May 3 & Princeton \\
\hline Simazine & Princep & 28 & .11 & June 8 & Blue Earth \\
\hline Propazine & Milogard & 26 & .06 & June 7 & Lamberton \\
\hline Propachlor & Ramrod & 21 & .51 & June 7 & Lamberton \\
\hline Prometon & Pramitol & 19 & .08 & August 9 & Park Rapids \\
\hline Ethalfluralin & Sonalan & 13 & .08 & June 25 & Princeton \\
\hline Trifluralin & Treflan & 9 & .21 & June 7 & Lamberton \\
\hline Propanil & Erban & 8 & .28 & May 3 & Blue Earth \\
\hline Terbacil & Sinbar & 7 & .07 & July 5 & Lamberton \\
\hline Pebulate & Tillam & 6 & .03 & October 4 & Lamberton \\
\hline Butylate & Sutan+ & 3 & .02 & October 4 & Crystal Springs \\
\hline Tebuthiuron & Spike & 2 & .01 & June 14 & Lamberton \\
\hline Triallate & Far-Go & 1 & .02 & June 7 & Princeton \\
\hline Benfluralin & Benefin & 0 & $<.01$ & -- & -- \\
\hline \multicolumn{6}{|c|}{ Insecticides } \\
\hline Methyl parathion & Penncap-M & 51 & .49 & June 14 & Minneapolis \\
\hline Azinphos-methyl & Guthion & 41 & 1.27 & July 5 & Lamberton \\
\hline Terbufos & Counter & 24 & 1.14 & May 3 & Princeton \\
\hline Chlorpyrifos & Lorsban & 22 & .06 & August 2 & Crystal Springs \\
\hline Fonofos & Dyfonate & 21 & .33 & July 5 & Lamberton \\
\hline Lindane & Lindane & 17 & .19 & September 27 & Lamberton \\
\hline Malathion & Cythion & 8 & .19 & July 5 & Lamberton \\
\hline Phorate & Thimet & 4 & .03 & August 2 & Princeton \\
\hline Permethrin & Ambush & 3 & .15 & July 5 & Lamberton \\
\hline Diazinon & Diazinon & 0 & $<.01$ & -- & -- \\
\hline Ethoprop & Mocap & 0 & $<.01$ & -- & -- \\
\hline
\end{tabular}



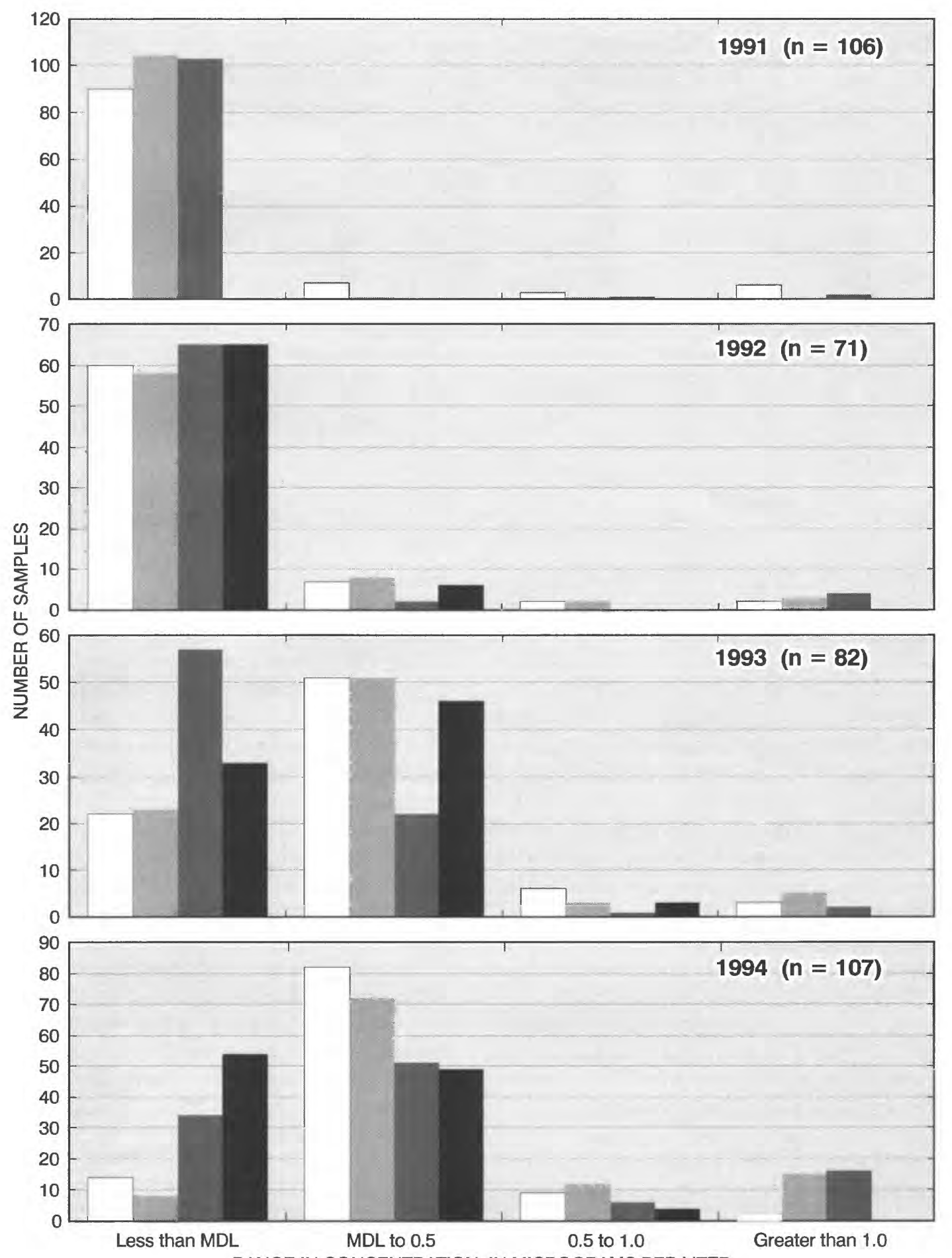

RANGE IN CONCENTRATION, IN MICROGRAMS PER LITER

MDL - Method Detection Limit

(0.05- 0.25 micrograms per liter in 1991-92;

$0.01-0.02$ micrograms per liter in 1993-94.)

$\mathrm{n}$ - Number of samples per year

\section{EXPLANATION}

\section{Alachlor Cyanazine}

Atrazine Metolachlor

Figure 7. Frequency distributions of four herbicides in rain for all sites, 1991-94. 


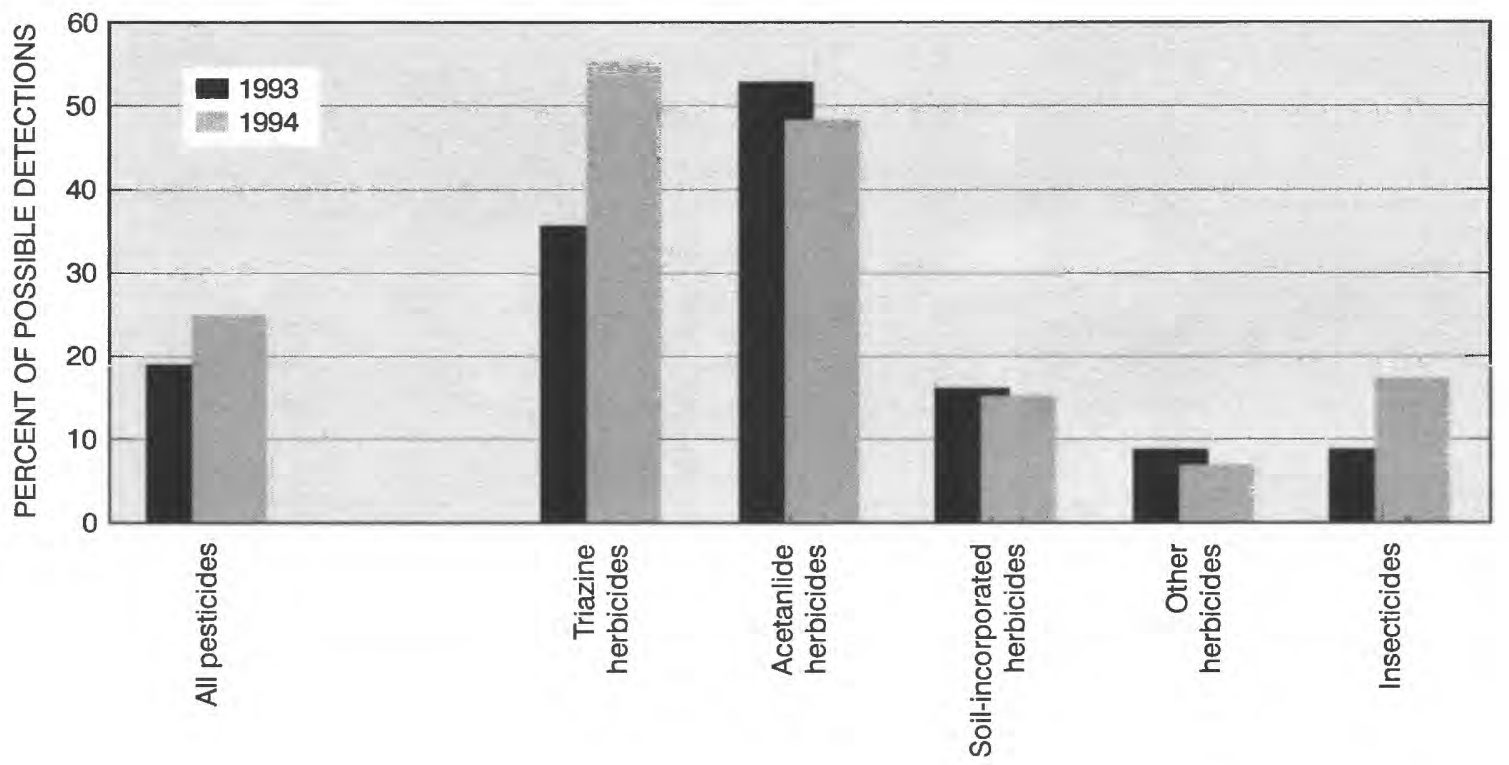

Figure 8. Percent of possible detections for all pesticides and five groupings, 1993-94.

in rain of this newly registered (in the United States) herbicide in its first season of use is important in several ways (Capel and others, 1995). Acetochlor is an acid amide, similar in structure to alachlor and metolachlor. The USEPA has mandated, as part of acetochlor's registration, that its use will reduce the use of the sum of the six of the most common corn herbicides (alachlor, atrazine, butylate, EPTC, metolachlor and 2,4-D) by 3 million kg during 1992-99, adjusted for differences in planted acreage (U.S. Environmental Protection Agency, 1994). Archived extracts of rain samples from 1993 were retrieved and analyzed for acetochlor, but the compound was not detected. Acetochlor appears to behave much like its analogs, alachlor and metolachlor, in its movement from the field into the hydrologic system. The presence of acetochlor in rain and surface water is expected based on the behavior of alachlor and metolachlor (Capel and others, 1995). The presence of this new herbicide in rain, in its first months of application, suggests that rain is a good matrix to monitor pesticides in the environment, and that rain provides a fast indicator of the movement of a pesticide from the site of application to the broader environment. Atmospheric measurements, such as rain or air, could be a valuable method to examine the short- and long-term presence or absence of certain pesticides as they become registered or after their current registration is withdrawn and they are no longer permitted to be used.

\section{Seasonal Patterns in Detections, Concentrations, and Fluxes}

To assess the seasonal behavior of atmospherically deposited pesticides, precipitation was continuously collected and analyzed (on a rain- or snow-event basis) from March 1989 through June 1990 in St. Paul or Rosemount (fig. 2). Three commonly used herbicidesalachlor, atrazine, and cyanazine-were studied. All three had similar seasonal patterns, although there were some minor differences (fig. 9). All three had maximum concentrations in precipitation during the spring of both years, immediately following application. Their concentrations decreased within weeks following application. Alachlor and cyanazine were at concentrations below the detection limit for most of the rain events after July 1989. Atrazine was detected in most rain events and many snow events throughout the year. This reflects the longer environmental persistence of atrazine, compared to alachlor and cyanazine. The presence of atrazine in snow, even when snow covered the ground locally, suggests either that its atmospheric residence time is long or that there is a continual source to the atmosphere and long-range atmospheric transport. It is possible that both are true.

The majority of the rain samples from late April/early May through the end of September had no detectable quantities of most of the target pesticides, although during May and June, most of the rain samples had detectable levels of some pesticides. The pattern of the highest concentrations occurring in the spring has held true for many of the pesticides every year. Data on the maximum concentration of each pesticide in rain, by sampling site and for the entire state, are shown in tables 3-6, and in tables 10-20 in the Supplemental Information section. Most of the maximum concentrations occurred in May or June, just as was observed in 1989 and 1990. For some compounds, the 


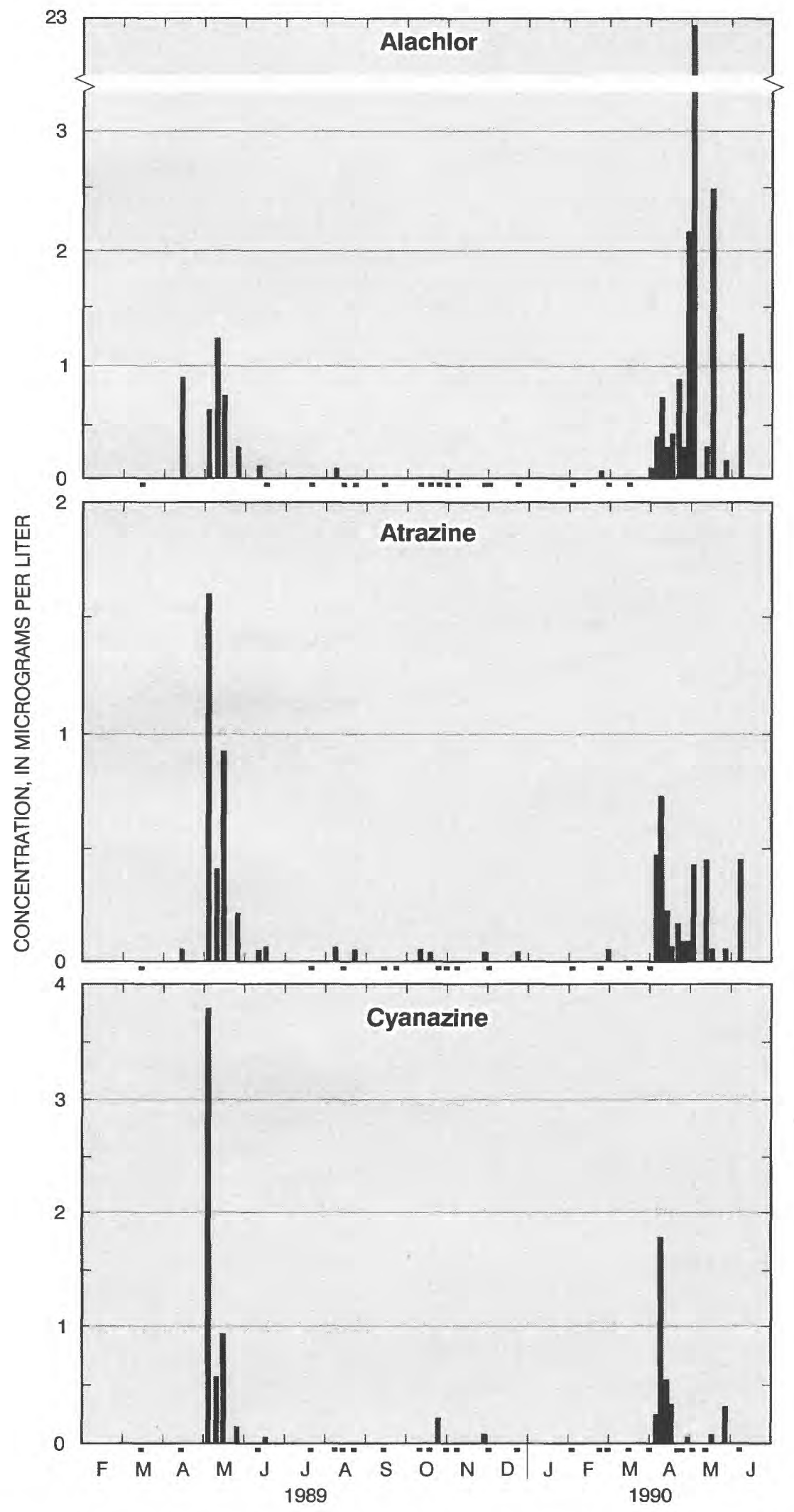

Figure 9. Concentrations of alachlor, atrazine, and cyanazine in rain or snow, in St. Paul (March 1989 to February 1990) and Rosemount, Minnesota (March 1990 to June 1990). (Dots below graphs represent rain or snow events in which the herbicides were not detected.) 
maximum concentration occurred later, August or September. This occurred for a few infrequently detected herbicides (table 5), some of which, such as prometon, have significant nonagricultural use, and for several of the insecticides (see the site-specific data, tables 10-20). This could be a result of late summer or autumn applications of these compounds.

The importance of the spring in the atmospheric deposition of pesticides can be seen in figure 10 . This graph presents the flux in micrograms per square meter per time period $\left(\mu \mathrm{g} / \mathrm{m}^{2} /\right.$ time period) in rain for two time periods. The early time period (about May through about June 15-the exact dates vary slightly between the two years because of the Tuesday sampling schedule) encompasses the application period for most herbicides and some insecticides in southern Minnesota. The later time period (about June 15 through about October 1) encompasses most of the remainder of the growing season when pesticides are applied less frequently. An example of the differences in pesticide fluxes between these two periods is shown by data for 1994. For all pesticide groups at all three sites, the flux in the spring/early summer is much greater than in the late summer/fall. In 1993, this pattern was not as definitive and even reversed for many of the groups at the Minneapolis site. This could be due to the unusual weather patterns (greater than normal amount of rain) and atypical timing of some applications of pesticides that occurred that year because of the wet spring.

\section{Temporal and Geographical Distribution of Fluxes in Rain}

Based on the data from 1989-90, it was determined that the highest concentrations of pesticides and the majority of the annual flux (greater than 99 percent) in rain occurred between May 1 and October 1 in Minnesota. Based on this conclusion, the duration of the sampling period was reduced each year to the five months (May through September) to decrease sampling and analysis costs. With the pesticide concentration data from these five months and the volume of total rainfall for each sample, total flux for the five month period was computed $\left(\mu \mathrm{g} / \mathrm{m}^{2} /\right.$ five months). From knowledge of the low levels of pesticide deposited during the October-April time period, the May through September flux was assumed to represent the annual flux $\left(\mu \mathrm{g} / \mathrm{m}^{2} /\right.$ year) for pesticides in precipitation in Minnesota. The weekly flux (mass per unit area) for each pesticide was obtained by multiplying the concentration of the pesticide in the rain by the amount of rainfall during that week (volume per unit area). The annual flux (based on data from May through September) was obtained by summing the weekly fluxes. The total yearly flux of pesticides at each site was obtained by summing the annual fluxes for all the pesticides ( 20 herbicides and 10 insecticides). The annual fluxes of pesticides in rain for the sampling sites active during 1993 and/or 1994 are presented in figure 11. Figure 11 can be used to compare the annual flux between the two sampling years (1993 and 1994) and between selected sites in Minnesota. Taken as a whole, the flux of pesticides in the rain in Minnesota is generally in the range of 200 to $2,000 \mu \mathrm{g} / \mathrm{m}^{2} /$ year. To put this flux in perspective, if a pesticide is applied yearly at the rate of $0.45 \mathrm{~kg} \mathrm{AI} / \mathrm{acre}$, then its "flux" to that field is about $1 \times 10^{8} \mu \mathrm{g} / \mathrm{m}^{2} /$ year. That is, the purposeful application of a pesticide is about 200,000 times as great as is deposited by rain, but the rain flux may be more significant in areas that are not treated with pesticides. Pesticides are deposited everywhere by the rain and have the potential to affect ecosystems for which they were not intended.

At every site with 1993 and 1994 data, the yearly flux of total pesticides was greater in 1994 than in 1993.

This is due to the linked variations in weather conditions and agricultural activities. In 1993, the spring and early summer was extremely wet and cool. In some areas of the state, crops were planted very late. The concentrations of pesticides measured in many rivers were greater than normal, because the heavy rains caused significant runoff from agricultural fields, carrying with it greater than normal quantities of pesticides. Overall there may have been a smaller source of pesticides available to the atmosphere in 1993 than in other years. In contrast, 1994 was a much more typical year in terms of rainfall, temperature, and agricultural practices. Compared to 1993, there was a greater flux of total pesticides in the rain in 1994, but it is somewhat surprising that this difference was largely due to one compound, cyanazine (fig. 12 and table 7). The relatively high concentrations and fluxes of cyanazine in rain was also observed by other investigators in 1994 compared to 1993 on Isle Royale in Lake Superior (E.M. Thurman, U.S. Geological Survey, oral commun., 1996). It is unknown whether this simply reflects an increase in the use of cyanazine in 1994 or whether it is due to other factors related to its agricultural or geographical use.

There were geographical differences in total pesticide flux from rain throughout the state that were consistent between the years (fig. 11 and table 7). Lamberton, which is in one of the most intensive row crop areas of the state, had the highest flux of any site sampled, both in 1993 and 1994. Its flux was 2.5 to 5 times higher than any other sampling site in both years. The other sites 


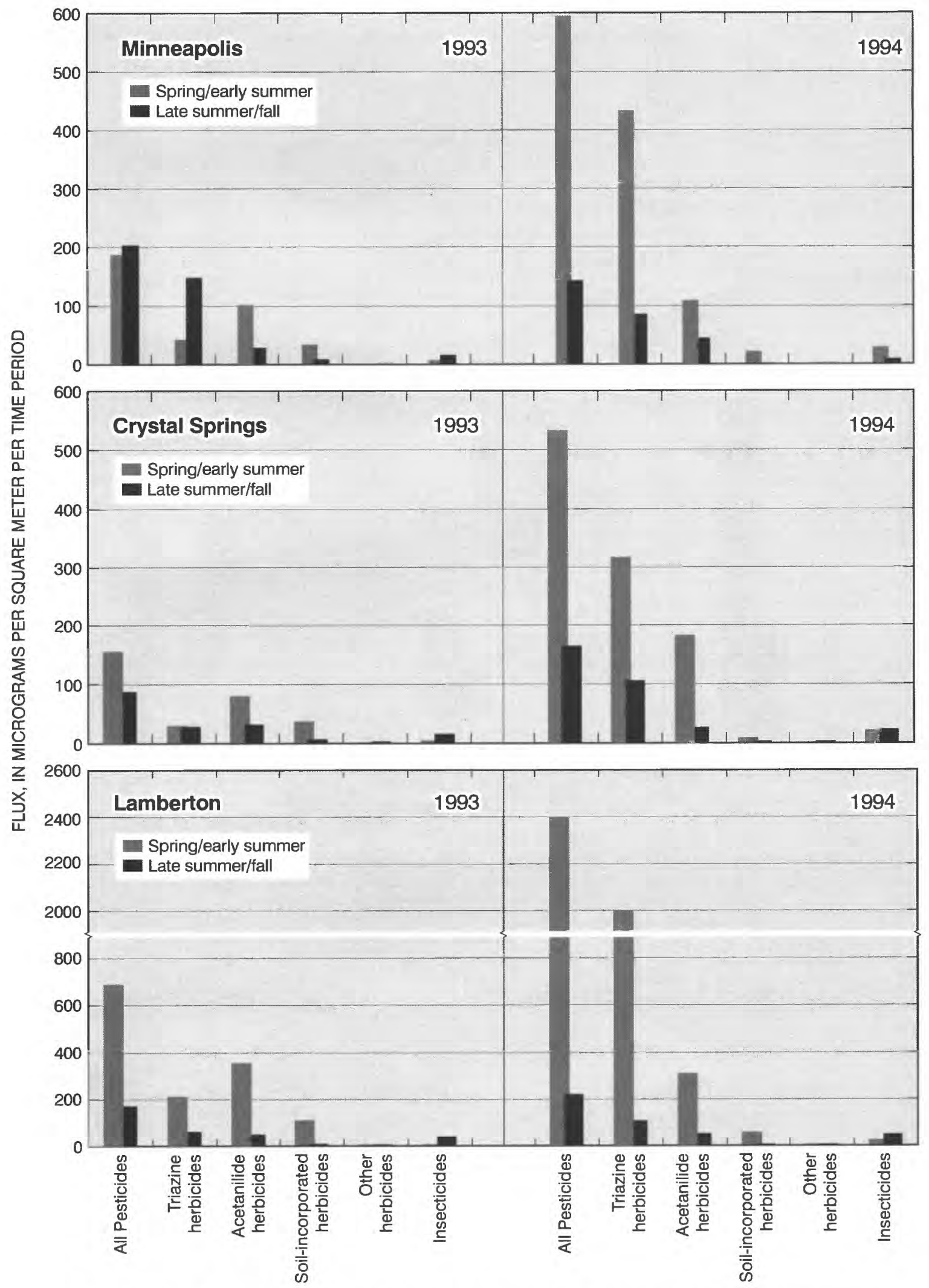

Figure 10. Flux of pesticides in rain at three sites during spring/early summer (about May 1 - June 15) and late summer/fall (about June 15 - October 1), 1993 and 1994. 


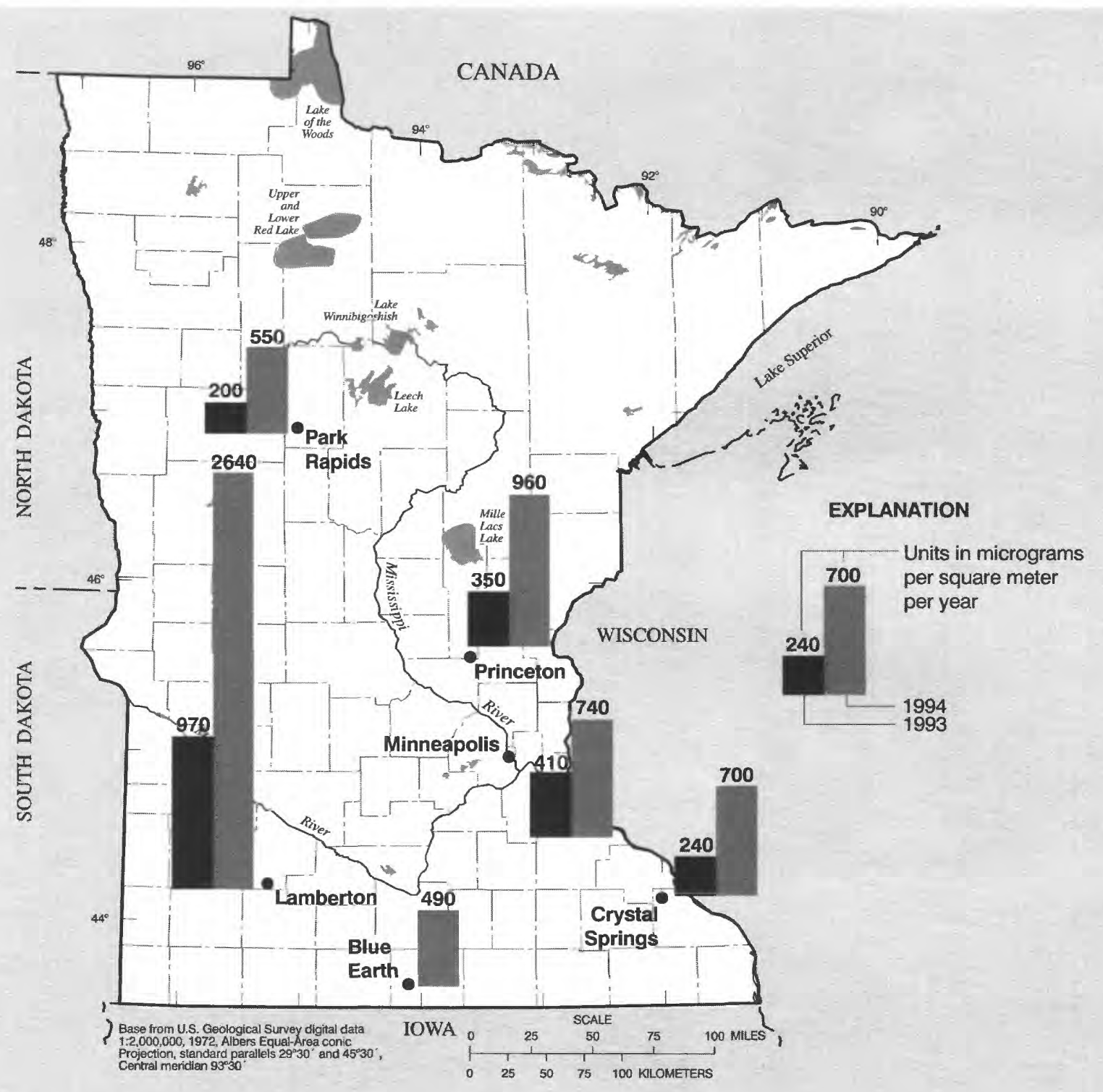

Figure 11. Fluxes of pesticides in rain at six sites, 1993 and 1994.

(Park Rapids, Princeton, Minneapolis, and Crystal Springs) all have similar pesticide fluxes in 1993 (200 to $410 \mu \mathrm{g} / \mathrm{m}^{2} /$ year) and 1994 ( 550 to $960 \mu \mathrm{g} / \mathrm{m}^{2} /$ year). These four sites are in areas of less intensive row-crop agriculture or in an urban area. These results suggest that there is a significant content of pesticides in rain regionally. The pesticides in the atmosphere are from a large geographical area, and transported with the prevailing wind currents. Other studies (Glotfelty and others, 1990; Goolsby and others, 1993) have shown that pesticides can be transported hundreds of miles before they are deposited to the surface by rain or other depositional mechanisms. This regional background occurrence of atmospheric pesticides is more reflective of wide geographical use of pesticides than of their use in the immediate area of the sampling site. Given this observation, it is notable that the site in an intensive row crop agricultural area, Lamberton, had a total pesticide flux that was considerably greater than the other sites. This suggests that there is also a local influence on the pesticide content of rain superimposed on the regional background. If there is a very strong local source of 

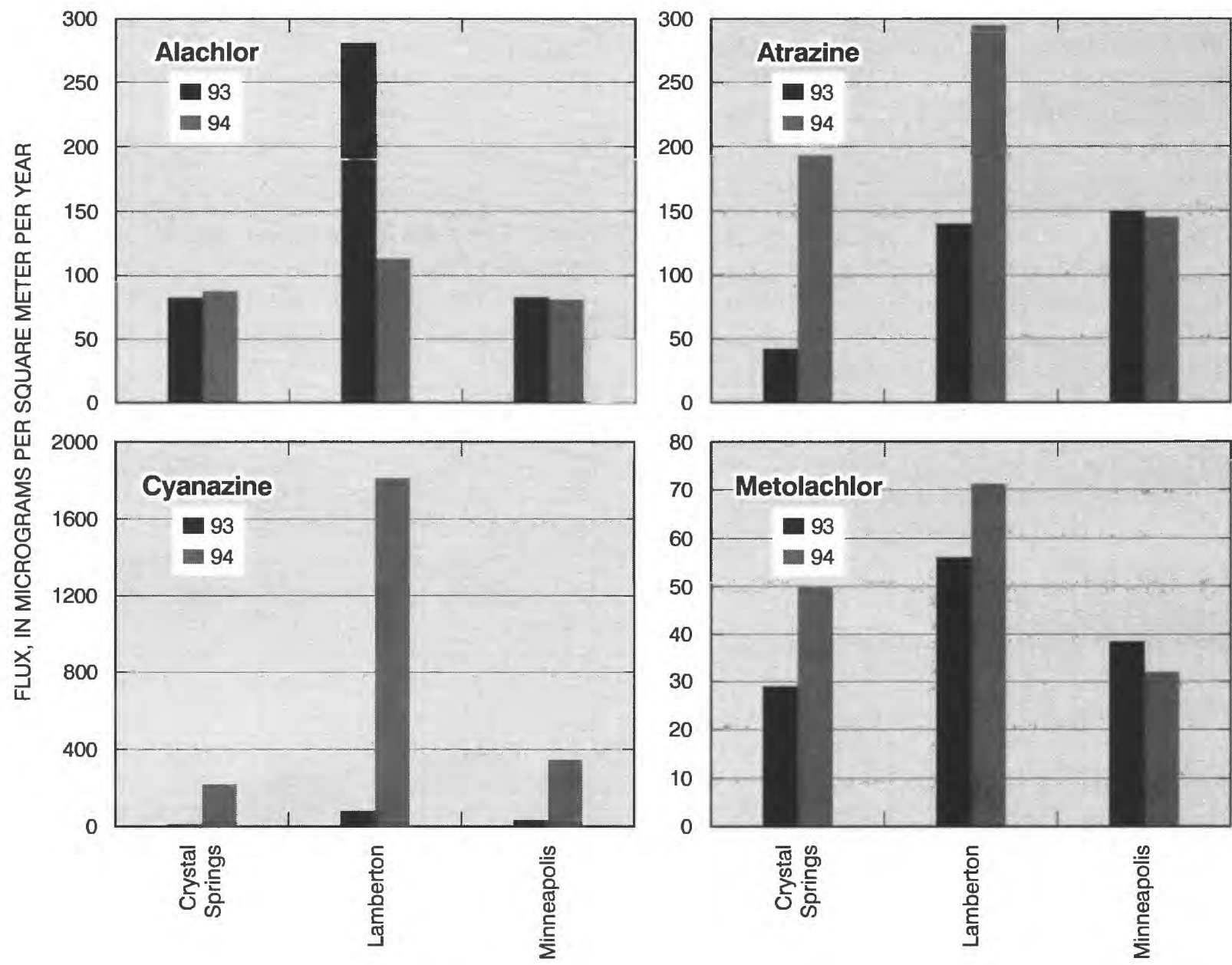

Figure 12. Fluxes of four high-use herbicides in rain at three sites, 1993 and 1994.

Table 7.-Total flux of all pesticides compared to the flux of cyanazine, 1993 and 1994. $\left[\mu \mathrm{g} / \mathrm{m}^{2} / \mathrm{yr}\right.$, micrograms per square meter per year]

\begin{tabular}{lcccccc}
\hline & \multicolumn{2}{c}{ All pesticides $\left(\mu \mathrm{g} / \mathrm{m}^{2} / \mathrm{yr}\right)$} & \multicolumn{2}{c}{ Cyanazine $\left(\mu \mathrm{g} / \mathrm{m}^{2} / \mathrm{yr}\right)$} & \multicolumn{2}{c}{ Percent due to cyanazine } \\
\cline { 2 - 6 } \multicolumn{1}{c}{ Site } & 1993 & 1994 & 1993 & 1994 & 1993 & 1994 \\
\hline Crystal Springs & 240 & 700 & 10 & 220 & 5 & 31 \\
Lamberton & 970 & 2,600 & 80 & 1,800 & 9 & 69 \\
Minneapolis & 410 & 740 & 30 & 350 & 8 & 47 \\
Park Rapids & 200 & 550 & 10 & 290 & 3 & 53 \\
Princeton & 350 & 960 & 10 & 450 & 4 & 47 \\
\hline
\end{tabular}

pesticides to the atmosphere, then there can be increased local deposition. The mechanisms through which pesticides enter the atmosphere include both volatilization and wind erosion of soil particles with their associated pesticides. The latter mechanism is a localized process because soil particles, especially larger particles, are deposited close to their source.
The observations of pesticides in rain in St. Paul (1989-90) and in Minneapolis (1992-94) contribute to the understanding of the transport and deposition of pesticides in the atmosphere. Most of the target compounds (with the exception of diazinon, lindane, malathion, permethrin, simazine, and trifluralin) are not registered for use in urban areas. The compounds that 
were most frequently detected in rain in Minneapolis (alachlor, atrazine, cyanazine, EPTC, metolachlor, and metribuzin) are not registered for use in urban areas. The presence of these compounds in urban rain, stormwater, and an urban lake (Wotzka and others, 1994) suggest that they are being transported through the atmosphere from agricultural areas and deposited by rain in the urban area. The total yearly flux of the four most frequently detected herbicides are shown on figure 12. The flux appears more consistent year to year in Minneapolis than in the more agricultural areas. Even the drastic increase in the cyanazine flux observed for Lamberton is diminished in Minneapolis. These data may indicate that an urban area may be an effective monitoring location for assessing changes in the regional atmospheric burden of agricultural pesticides deposited by rain.

\section{Potential Significance to Surface-Water Quality}

Rain samples, during 1989-94, had maximum concentrations of alachlor, atrazine and cyanazine of 22 , 2.9 , and $24 \mu \mathrm{g} / \mathrm{L}$ (tables 2,5 and 6 , respectively). These compounds were the only three pesticides with concentrations greater than $2 \mu \mathrm{g} / \mathrm{L}$. In general, the maximum concentrations of these three herbicides in rain occurred in late May through June. These data from Minnesota agree with results from Iowa (Nations and Hallberg, 1992) and the midwestern United States (Goolsby and others, 1993). Although there is very little actual connection between rain and drinking water, it is informative to compare the rain concentrations with these benchmark values. For alachlor and atrazine, the USEPA primary drinking water standards (maximum contamination level (MCL)) are 2 and $3 \mu \mathrm{g} / \mathrm{L}$, respectively (Nowell and Resek, 1994). The maximum contamination level goal (MCLG) for cyanazine is 1 $\mu \mathrm{g} / \mathrm{L}$ (Nowell and Resek, 1994). Most of the measured concentrations of these herbicides in rain are much lower than this, but the maximum concentrations in the spring rain have exceeded the drinking water standards. There is some indication that the volume of rain effects the concentration of the pesticides (Richards and others, 1987). As an example from the present study, the rain event that resulted in the maximum alachlor concentration of $22 \mu \mathrm{g} / \mathrm{L}$ was from a very small storm ( $<0.1$ in. of rain). Capel (1991) reported that within a single rain event, the maximum concentrations occur during the first few millimeters of rainfall and these concentrations can be one order of magnitude or greater than the concentrations measured in the complete "integrated" rain event. This means that during the beginning of a rain event the flora experience relatively high concentrations of pesticides. These concentrations continually decreased throughout the rain event. The environmental significance of this is unknown.

One way of assessing the potential significance of pesticides in rain to surface-water quality is to compare the relative magnitudes of the pesticide flux to a watershed from rainfall and the flux of pesticides from that watershed in the river. This was done for the Middle Branch of the Whitewater River (near Crystal Springs) in 1993 and 1994, for a small watershed that discharges into Lake Harriet, Minneapolis in 1993 and 1994, and for the East Fork of the Blue Earth River (near Blue Earth) in 1994. The comparative fluxes for these three watersheds in stormwater runoff and rain are shown for four herbicides in figure 13. In almost every case the yearly flux in the rain is much greater than the flux in the river (except in the Whitewater River Basin in 1993). This implies that a large fraction of the pesticides deposited to the watershed in the rain is retained within the watershed. If this is viewed on a weekly basis, rather than the yearly sum, the observations are the same. Figures 14 and 15 show the cumulative flux of example pesticides in the rain and the river over time for the watershed discharging to Lake Harriet (Minneapolis) and the watershed of the Middle Branch of the Whitewater River (near Crystal Springs), respectively. Because the same area and time period were used in the calculations for both the rain and the river, the cumulative fluxes correspond to the fluxes from the rain to the watershed and to the river from the watershed. The cumulative fluxes of the pesticides in both of these systems show that contributions from the rain to the watershed occur earlier in the year than do the contributions to the river from the watershed. This suggests that the herbicides from the rainfall (evidence of long-range transport) enter the watersheds earlier than the local application or that pesticides applied in the basin take longer to go from the fields to the stream as they are processed through the soils and drainage system.

The herbicides shown in figure 14 (alachlor, atrazine, cyanazine, and metolachlor) are not used within the Lake Harriet watershed in the urban area of Minneapolis. Thus, the source for all of these herbicides to the basin is the atmosphere. The flux in rain generally was greater than the flux in the river (stormwater) for all four herbicides in both years (fig. 13). The summed flux of the four herbicides in rain was about 40 and 210 times greater than in the stormwater in 1993 and 1994, respectively. (The greater difference in 1994 can be almost entirely accounted for by 

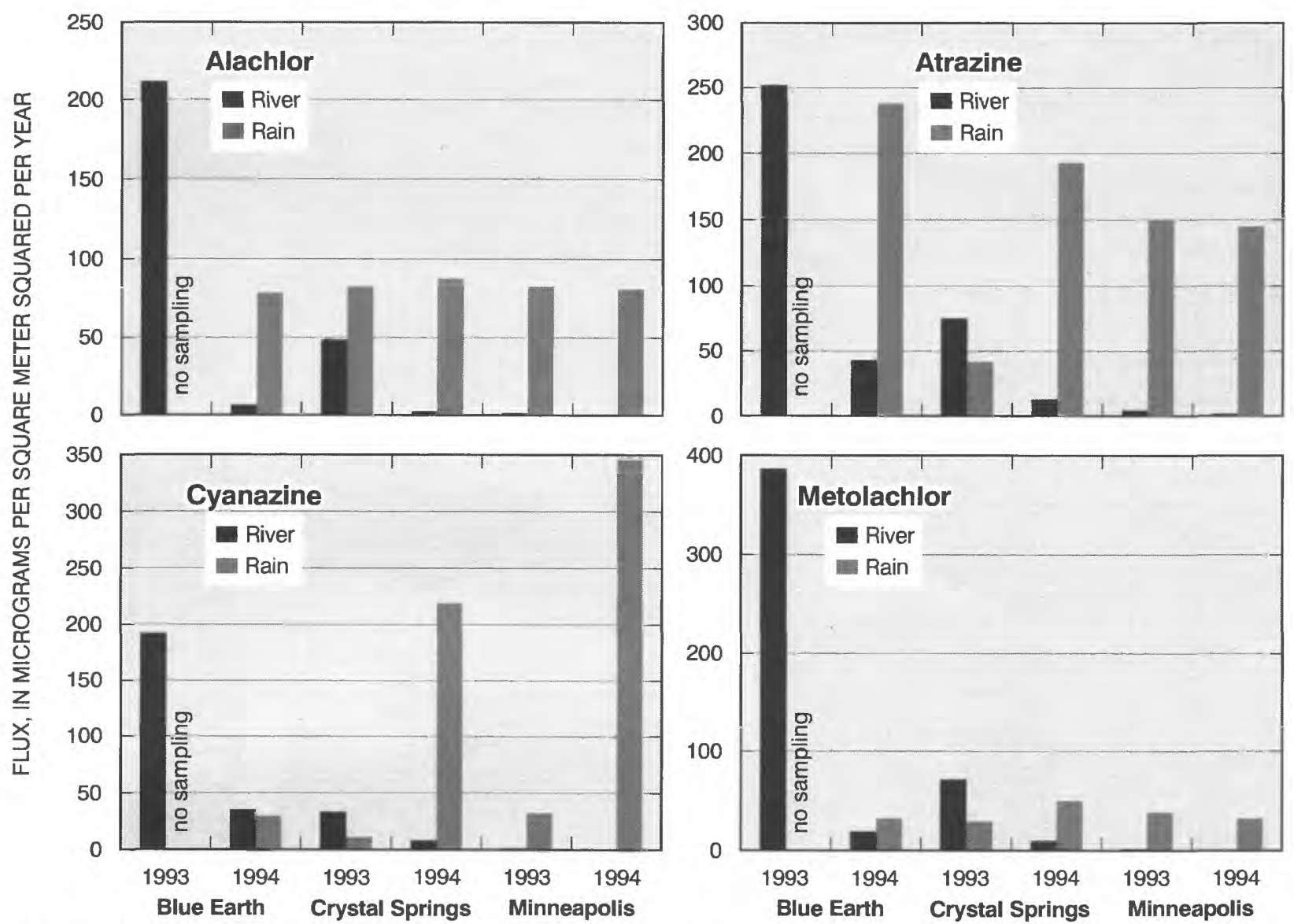

Figure 13. Fluxes in river water and rain of four herbicides in three watersheds, 1993 and 1994.

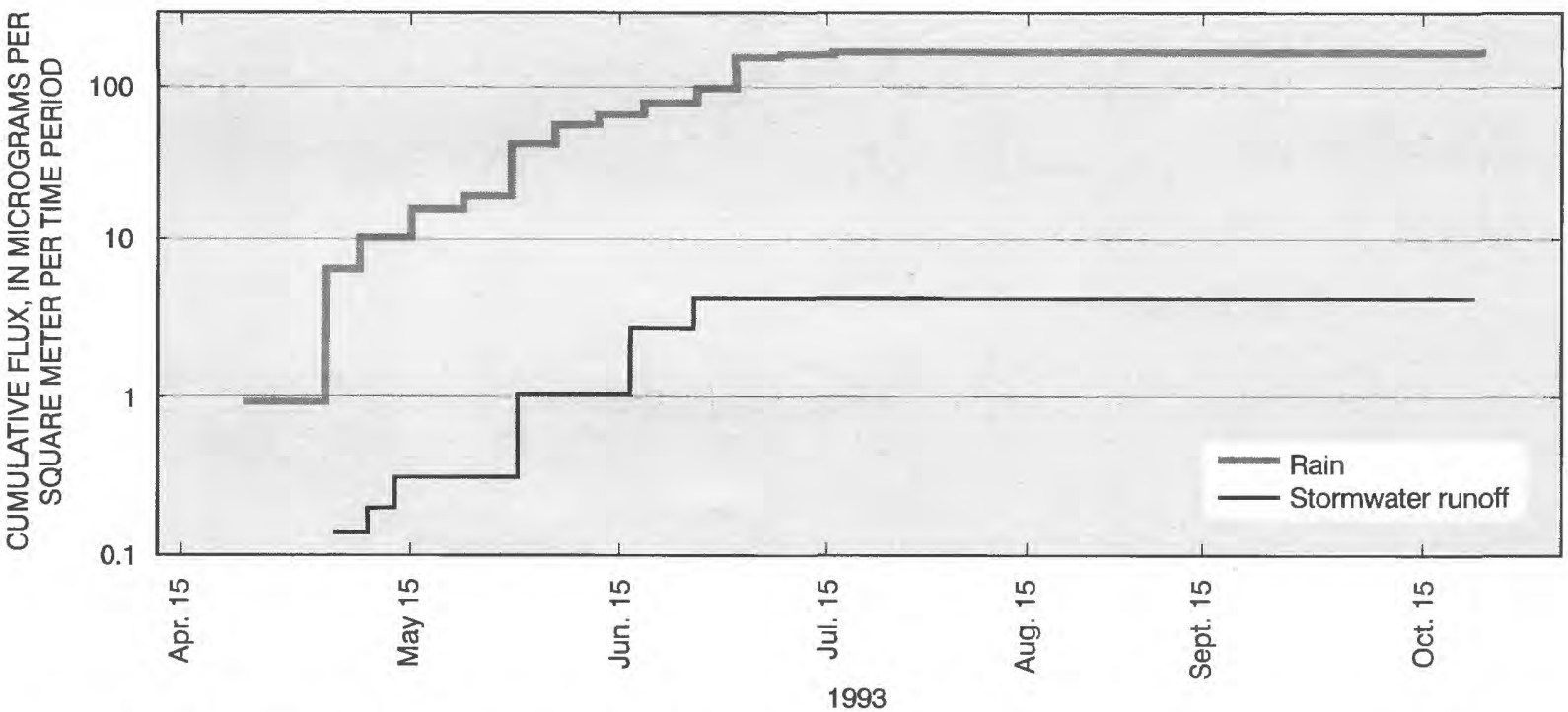

Figure 14. Cumulative flux of the sum of alachlor, atrazine, cyanazine and metolachlor in storm water runoff and rain in a small watershed that discharges to Lake Harriet, Minneapolis, Minnesota, during 1993. 

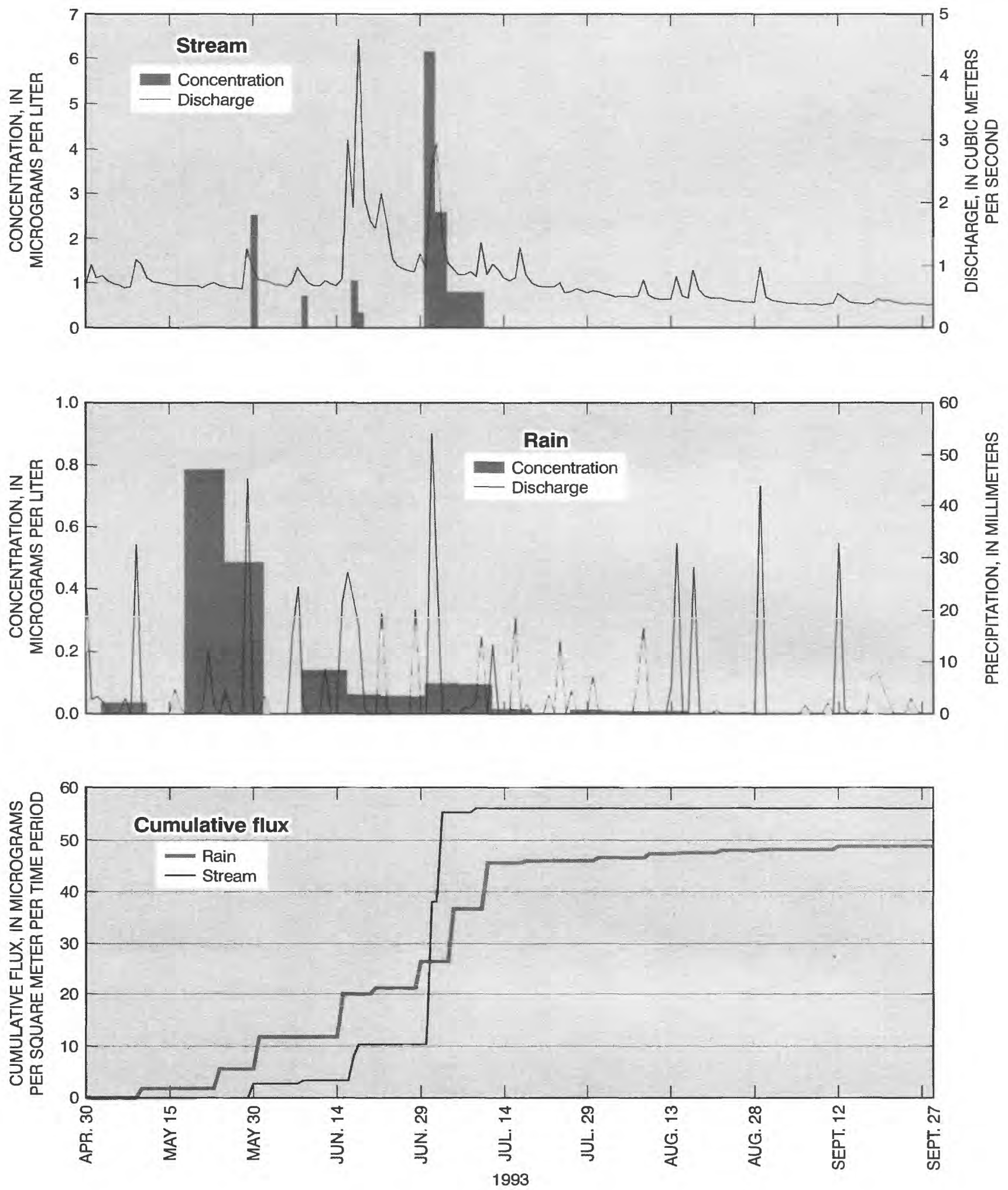

Figure 15. Concentrations and cumulative flux of alachlor in the Middle Branch of the Whitewater River and in rain near Crystal Springs, Minnesota, 1993. 
cyanazine). This implies that a large fraction of these herbicides, and probably all pesticides, deposited to the urban watershed in the rain are retained and degraded within the watershed. The urban landscape (less the impervious fraction) is efficient at inhibiting the transport of the pesticides. If the rain is assumed to be the total source of these herbicides to this watershed, then the percent loss in runoff can be estimated. In 1993 , only $1.6,2.6,1.7$, and 1.7 percent of the alachlor, atrazine, cyanazine, and metolachlor, respectively, and in 1994, only $0.4,1.0,0.01$, and 2.8 percent of the alachlor, atrazine, cyanazine, and metolachlor, respectively, that was deposited in rain found the stormwater runoff. It is interesting to note that these percentages are similar to those observed in the whole of the Minnesota River Basin, an area of intense row crop agriculture (fig. 2). Schottler and others (1992) reported that $0.7,1.3,1.7$, and 1.6 percent of the alachlor, atrazine, cyanazine, and metolachlor, respectively, that were used in the Minnesota River Basin were observed in the Minnesota River.

In the Whitewater River Basin, the flux of herbicides in the river was generally much closer to the flux of herbicides in the rain in 1993 (fig. 15), which was a year of abnormally large rainfalls and high streamflows. Figure 15 illustrates the relation between alachlor in the river and in rain. The upper plot represents the stream discharge and herbicide concentration in the river. A typical pattern (Thurman and others, 1991; Schottler and others, 1992; Larson and others, 1995) of low concentrations in early spring is observed, followed by peak concentrations with strong discharge events in late spring and early summer, followed by low or nondetectable concentrations throughout the rest of the season. The middle plot represents the rainfall amount and the herbicide concentration from the weekly rain sample. The seasonal pattern of concentration in rain is similar to the pattern observed in previous studies (Capel, 1991; Goolsby and others, 1993). The peak concentrations in rain often precede or coincide with the peak concentrations in the streams. The seasonal patterns of herbicides in rain and in the stream are similar and both correspond with the local use of herbicides with spring planting. The early peak concentrations in rain suggest that either atmospheric removal is efficient or there is long-range transport of these herbicides. The bottom plot presents a comparison of the magnitude of these two transport processes: atmospheric deposition (quantified as cumulative mass in rain) versus runoff from fields (quantified as cumulative mass in the stream). The total water discharged from Middle Branch of the Whitewater River and total rainfall to this watershed during May through September 1993, were estimated to be about $1.0 \times 10^{7}$ and $4.5 \times 10^{7} \mathrm{~m}^{3}$, respectively. The cumulative mass of alachlor, atrazine, cyanazine and metolachlor from precipitation to the watershed are 2.7 , $5.4,1.9$ and $0.7 \mathrm{~kg}$, respectively. The cumulative mass of alachlor, atrazine, cyanazine and metolachlor in the stream are $3.1,6.1,2.2$ and $4.7 \mathrm{~kg}$, respectively. They are all less than 1 percent of the same herbicides, respectively, applied in Winona County (Kelly and Hines, 1990. Gianessi and Puffer, 1991). For the herbicides alachlor, atrazine, and cyanazine the magnitude of the masses are very similar between the stream and the rain. The ratio of the masses between the rain and stream ranged from almost equal for cyanazine and metolachlor to a factor of about five for alachlor. That is, the amount of these herbicides falling in the rain within the river's watershed is similar to the amount of the herbicides entering the river through stormwater runoff. This is true even though the concentrations in the river were about one order of magnitude greater than in the rain. This is not to imply that the same molecules of a chemical that fall from the sky enter the surface water; but that the magnitude of the two processes, for these herbicides, are very similar. For the two years that were included in this study, this similarity between the masses in the rain and stream for the Whitewater River was different compared to the other two basins. For all other sites in almost all years, the magnitude of the flux in the rain to the basin was much greater than the flux in the river (fig. 13). These data suggest that the importance of the atmosphere in distributing the current-use pesticides throughout the hydrologic system is equal to or greater than the importance of surfacewater runoff, yet there has been only limited investigations on the atmospheric transport and deposition of pesticides.

\section{Summary and Conclusions}

Rain was sampled across Minnesota for pesticides used in the midwest during 1989. Snow was sampled during 1989 and 1990. The number of sampling sites during any one year ranged from one to eight. Most were located in the southern two-thirds of the State and included a site located in a large urban area. The total number of compounds monitored increased from 4 in (1989-90) to 32 (in 1994) and included both insecticides and herbicides. In situ pesticide isolation from water was developed to minimize loss and facilitate sample transport. Total volume of precipitation was monitored to calculate the flux of pesticides in rainfall during each sampling period.

All of the rain samples throughout the growing season had detectable quantities of at least one pesticide, 
but most of the pesticides were only infrequently observed. The most frequently detected compounds were the herbicides alachlor, atrazine, cyanazine, and metolachlor, and in 1994, its first year of registration, acetochlor. Peak concentrations of most herbicides in rain occurred shortly after their application periods in the spring. Peak concentrations of most of the insecticides occurred later in the summer.

The vast majority of the wet depositional flux of total pesticide occurred between early May and October. The annual variability in pesticide deposition can be explained by year-to-year differences in climate and pesticide use patterns. The one sampling site (Lamberton) that was in an area dominated by row-crop agriculture showed a substantially greater annual flux than the other sampling sites that were in areas of either less intensive agriculture or urbanization. Regional deposition, away from a local source, can be inferred from the results for these other sites because they have annual pesticide fluxes that are very similar for any given year. The observation of agricultural pesticides (not registered for home and garden use) in rain and stormwater runoff in the urban area indicates their transport from areas of agricultural use. The regional deposition suggests that urban areas may be effective monitoring locations for assessing changes in the regional atmospheric burden of agricultural pesticides deposited by rain. The data collected from Minneapolis for acetochlor and cyanazine support this suggestion.

The study quantified and compared the pesticide flux in streams out of small watersheds and the pesticide flux deposited to the watersheds in rain. The data indicate that the flux into the watershed from the rain is generally much greater than the flux from the watershed in the stream. For the urban area, on the order of 98 percent of the flux in the rain and runoff for the four most commonly observed herbicides is retained by the watershed.

\section{References}

Aspelin, A.L., 1994, Pesticides industrial sales and usage, 1992 and 1993 market estimates: U.S. Environmental Protection Agency, Washington, D.C., 733-K-94-001, 33 p.

Bester, K., Huhnerfuss, H., Neudorf, B., and Thiemann, W., 1995, Atmospheric deposition of triazine herbicides in northern Germany and the German Bight (North Sea): Chemosphere, v. 30, p. 16391653.
Bidleman, T.F., 1988, Atmospheric processes-Wet and dry deposition of organic compounds are controlled by their vapor-particle partitioning: Environmental Science and Technology, v. 22, p. 361-367.

Bidleman, T.F., Wideqvist, U., Jansson, B., and Soderlund, R., 1987, Organochlorine pesticides and polychlorinated biphenyls in the atmosphere of southern Sweden: Atmospheric Environment, v. 21, p. 641-654.

Brun, G.L., Howell, G.D., and O'Neill, H.J., 1991, Spatial and temporal patterns of organic contaminants in wet precipitation in Atlantic Canada: Environmental Science and Technology, v. 25, p. 1249-1261.

Buser, H.R., 1990, Atrazine and other s-triazine herbicides in lakes and in rain in Switzerland: Environmental Science and Technology, v. 24, p. 1049-1058.

Capel, P.D., 1991, Wet atmospheric deposition of herbicides in Minnesota, in U.S. Geological Survey Toxic Substances Hydrology ProgramProceedings of the Technical Meetings, G.E. Mallard, and D.A. Aronson (eds), Monterey, California: U.S. Geological Survey WaterResources Investigations Report 91-4034, p. 334337.

Capel, P.D., Leuenberger, C., and Giger, W., 1991, Hydrophobic organic chemicals in urban fog: Atmospheric Environment, v. 25A, p. 1346-1355.

Capel, P.D., Ma, L., Schroyer, B.R., Larson, S.J., and Gilchrist, T.A., 1995, Analysis and detection of the new corn herbicide Acetochlor in river water and rain: Environmental Science and Technology, v. 29 , p. 1702-1705.

Chan, C.H., and Perkins, L.H., 1989, Monitoring of trace organic contaminants in atmospheric precipitation: Journal of Great Lakes Research, v. 15 , p. 465-475.

Czuczwa, J., Leuenberger, C., and Giger, W., 1988, Seasonal and temporal changes of organic compounds in rain and snow: Atmospheric Environment, v. 22, p. 907-916. 
Daines, R.H., 1952, 2,4-D as an air pollutant and its effect on various species of plants, in Air Pollution: Proceedings of the United States Technical Conference on Air Pollution, L.C. McCabe, (ed): McGraw-Hill Book Co., Inc., New York, p. 140143.

Eichers, T., Andrilenas, P., Jenkins, R., and Fox, A., 1968, Quantities of pesticides used by farmers in 1964: Agricultural Economic Report, 131, Economic Research Service, U.S. Department of Agriculture, $31 \mathrm{p}$.

Eisenreich, S.J., Hollod, G.J., and Johnson, T.C., 1981a, Atmospheric concentrations and deposition of polychlorinated biphenyls to Lake Superior, in S.J. Eisenreich (ed.), Atmospheric Pollutants in Natural Waters: Ann Arbor Science, p. 425-444.

Eisenreich, S.J., Looney, B.B., and Thornton, J.D., 1981b, Airborne organic contaminants in the Great Lakes ecosystem: Environmental Science and Technology, v. 15 , p. $30-38$.

Franz, T.P., 1994, Deposition of semivolatile organic chemicals in snow: Ph.D. Thesis, University of Minnesota, $397 \mathrm{p}$.

Franz, T.P., Eisenreich, S.J., and Swanson, M.B., 1991, Evaluation of precipitation samplers for assessing atmospheric fluxes of trace organic contaminants: Chemosphere, v. 23, p. 343-362.

Gianessi, L.P., and Puffer, C., 1991, Herbicide use in United States: National Summary Report, Resources for the Future, Washington D.C., 128 p.

-1992, Insecticide use in U.S. crop production: Resources for the Future, Washington D.C., 108 p.

Gilliom, R.J., Alexander, R.B., and Smith, R.A., 1985, Pesticides in the Nation's rivers, 1975-1980, and implications for future monitoring: U.S. Geological Survey Water-Supply Paper 2271, 26 p.

Glotfelty, D.E., Majewski, M.S., and Seiber, J.N., 1990, Distribution of several organophosphorus insecticides and their oxygen analogues in a foggy atmosphere: Environmental Science and Technology, v. 24, p. 353-357.

Glotfelty, D.E., Seiber, J.N., and Liljedahl, L.A., 1987, Pesticides in fog: Nature, v. 325, p. 602-605.
Glotfelty, D.E., Williams, G.H., Freeman, H.P., and Leech, M.M., 1990, Regional atmospheric transport and deposition of pesticides in Maryland, in D.A. Kurtz (ed), Long Range Transport of Pesticides: Lewis Publishers, Inc., Chelsea, Michigan, p. 199222.

Goolsby, D.A., Thurman, E.M., Pomes, M.L., and Battaglin, W.A., 1993, Occurrence, deposition, and long range transport of herbicides in precipitation in the midwestern and northeastern United States, in Selected Papers on Agricultural Chemicals in Water Resources of the Midcontinental United States: U.S. Geological Survey Open-File Report 93-418, p. $75-89$

Haraguchi, K., Kitamura, E., Yamashita, T., and Kido, A., 1995, Simultaneous determination of trace pesticides in urban precipitation: Atmospheric Environment, v. 29, p. 247-253

Kelly, P.L., and Hines, J.W., 1990, Pesticide use in rural Minnesota: State of Minnesota, Department of Agriculture, $45 \mathrm{p}$.

Kurtz, D.A.(ed), 1990, Long range transport of pesticides: Lewis Publishers, Inc., Chelsea, Michigan, $432 \mathrm{p}$.

Larson, S.J., Capel, P.D., Goolsby, D.A., Zaugg, S.D., and Sandstrom, M.W., 1995, Relations between pesticide use and riverine flux in the Mississippi River Basin: Chemosphere, v. 31, p. 3305-3321.

Leuenberger, C., Czuczwa, J., Heyerdahl, E., and Giger, W., 1988, Aliphatic and polycyclic aromatic hydrocarbons in urban rain, snow and fog: Atmospheric Environment, v. 22, p. 695-705.

Leuenberger, C.L., Ligocki, M.P., and Pankow, J.F., 1985, Trace organic compounds in rain. 4. Identities, concentrations, and scavenging mechanisms for phenols in urban air and rain: Environmental Science and Technology, v.19, p. 1053-1058.

Ligocki, M.P., Leuenberger, C.L., and Pankow, J.F., 1985a, Trace organic compounds in rain. 2. Gas scavenging of neutral organic compounds: Atmospheric Environment, v. 19, p. 1609-1617. 
-1985b, Trace organic compounds in rain-3. Particle scavenging of neutral organic compounds, Atmospheric Environment, v. 19, 1619-1626.

Majewski, M.S., and Capel, P.D., 1995, Pesticides in the atmosphere, distribution, trends, and governing factors: Ann Arbor Press, Chelsea, Michigan, 214 p.

National Atmospheric Deposition Program, 1988, Instruction manual, NADP/NTN Site Operation: National Resource Ecology Laboratory, Colorado State University, Fort Collins, Colorado, 56 p.

Nations, B.K., and Hallberg, G.R., 1992, Pesticides in Iowa precipitation: Journal of Environmental Quality, v. 21, p. 486-492.

Nowell, L.H., and Resek, E.A., 1994 National standards and guidelines for pesticides in water, sediment, and aquatic organisms-Application to water-quality assessments: Reviews of Environmental Contamination and Toxicology, v. 140, p. 1-164.

Pankow, J.F., Isabelle, L.M., and Asher, W.E., 1984, Trace organic compounds in rain. 1. Sampler design and analysis by Adsorption/Thermal Desorption (ATD): Environmental Science and Technology, v. 18, p. $310-318$.

Patton, G.W., Hinchley, D.A., Walla, M.D., and Bidleman, T.F., 1989, Airborne organochlorines in the Canadian High Arctic: Tellus, v. 41B, p. 243255.

Richards, R.P., Kramer, J.W., Baker, D.B., and Krieger, K.A., 1987, Pesticides in rainwater in the northeastern United States: Nature, v. 327, p. 129131.

Roberts, J.K., and Wojciechowski, D., 1986, Directory of precipitation monitoring sites, Volume 1: National Atmospheric Deposition Program, Fort Collins, Colorado, $247 \mathrm{p}$.

Scharf, J., Wiesiollek, R., and Bachmann, K., 1992, Pesticides in the atmosphere: Fresenius Zeitung fur Analytische Chemie, v. 342, p. 813-816.

Schomburg, C.J., Glotfelty, D.E., and Seiber, J.N., 1991, Pesticide occurrence and distribution in fog collected near Monterey, California: Environmental Science and Technology, v. 25, p. 155-160.
Schottler, S.P., Eisenreich, S.J., and Capel, P.D., 1992, Atrazine, alachlor, and cyanazine in a large agricultural river system: Environmental Science and Technology, v. 28, p. 1079-1089.

Squillace, P.J., Thurman, E.M., and Furlong, E.T., 1993, Groundwater as a nonpoint source of atrazine and deethylatrazine in a river during base flow conditions: Water Resources Research, v. 29, p. 1719-1729.

Strachan, W.M., and Eisenreich, S.J., 1990, Mass balance accounting of chemicals in the Great Lakes, in D.A. Kurtz (ed), Long Range Transport of Pesticides: Lewis Publishers, Inc., Chelsea, Michigan, p. 291-301.

Tatsukawa, R., Yamaguchi, Y., Kawano, M., Kannan, N., and Tanabe, S., 1990, Global monitoring of organochlorine insecticides-An 11-year case study (1975-1985) of HCHs and DDTs in the open ocean atmosphere and hydrosphere, in D.A. Kurtz (ed), Long Range Transport of Pesticides: Lewis Publishers, Inc., Chelsea, Michigan, p. 127-141.

Thurman, E.M., Goolsby, D.A., Meyer, M.T., and Kolpin, D.W., 1991, Herbicides in surface waters of the midwestern United States-The effect of spring flush: Environmental Science and Technology, v. 25, p. 1794-1796.

Tornes, L.H., 1991, Stream water quality-Minnesota, National Water Summary 1990-91: U.S. Geological Survey Water-Supply Paper 2400, p. 335-342.

Tsal, W., and Cohen, Y., 1991, Dynamic partitioning of semivolatile organics in gas/particle/rain phases during rain scavenging: Environmental Science and Technology, v. 25, p. 2012-2023.

United States Environmental Protection Agency, 1994, Prevention, pesticides and toxic substances, questions and answers, Conditional Registration of Acetochlor: U.S. Environmental Protection Agency, Washington, D.C., 18 p.

University of Minnesota, 1992, Cultural and chemical weed control in field crop: Minnesota Extension Service, Agriculture, University of Minnesota, ERG-BU-3157-S, 27 p. 
Valsaraj, K.T., Them, G.J., Reible, D.D., and Thibodeaux, L.J., 1993, On the enrichment of hydrophobic organic compounds in fog droplets: Atmospheric Environment, v. 27A, p. 203-210.

Van Noort, P.C.M., and Wondergem, E., 1985, Scavenging of airborne polycyclic aromatic hydrocarbons by rain: Environmental Science and Technology, v. 19, p. 1044-1048.

Welch, H.E., Muir, C.G., Billeck, B.N., Lockhart, W.L., Brunskill, G.J., Kling, H.J., Olson, M.P., and Lemoine, R.M., 1991, Brown snow-A long-range transport event in the Canadian Arctic:

Environmental Science and Technology, v. 25, p. 80-286.

Wotzka, P.J., Lee, J., Capel, P., Ma, L., 1994, Pesticide concentrations and fluxes in an urban watershed, in Proceedings of the American Water Resources Association's National Symposium on Water Quality: American Water Resources Association Technical Publication TPS-94-4, Herndon, VA, p. 135-145.

Wu, T.L., 1981, Atrazine residue in esturine water and the aerial deposition of atrazine into Rhode River, Maryland: Water, Air, and Soil Pollution, v. 15, p. 173-184.

Zaugg, S.D., Sandstrom, M.W., Smith, S.G., and Fehlberg, K.M., 1995, Method of analysis by the USGS/NWQL-determination of pesticides in water by $\mathrm{C}-18$ solid-phase extraction and capillarycolumn gas chromatography with selective-ion monitoring: U.S. Geological Survey Open-File Report 95-181, 65 p. 
Supplemental Information 


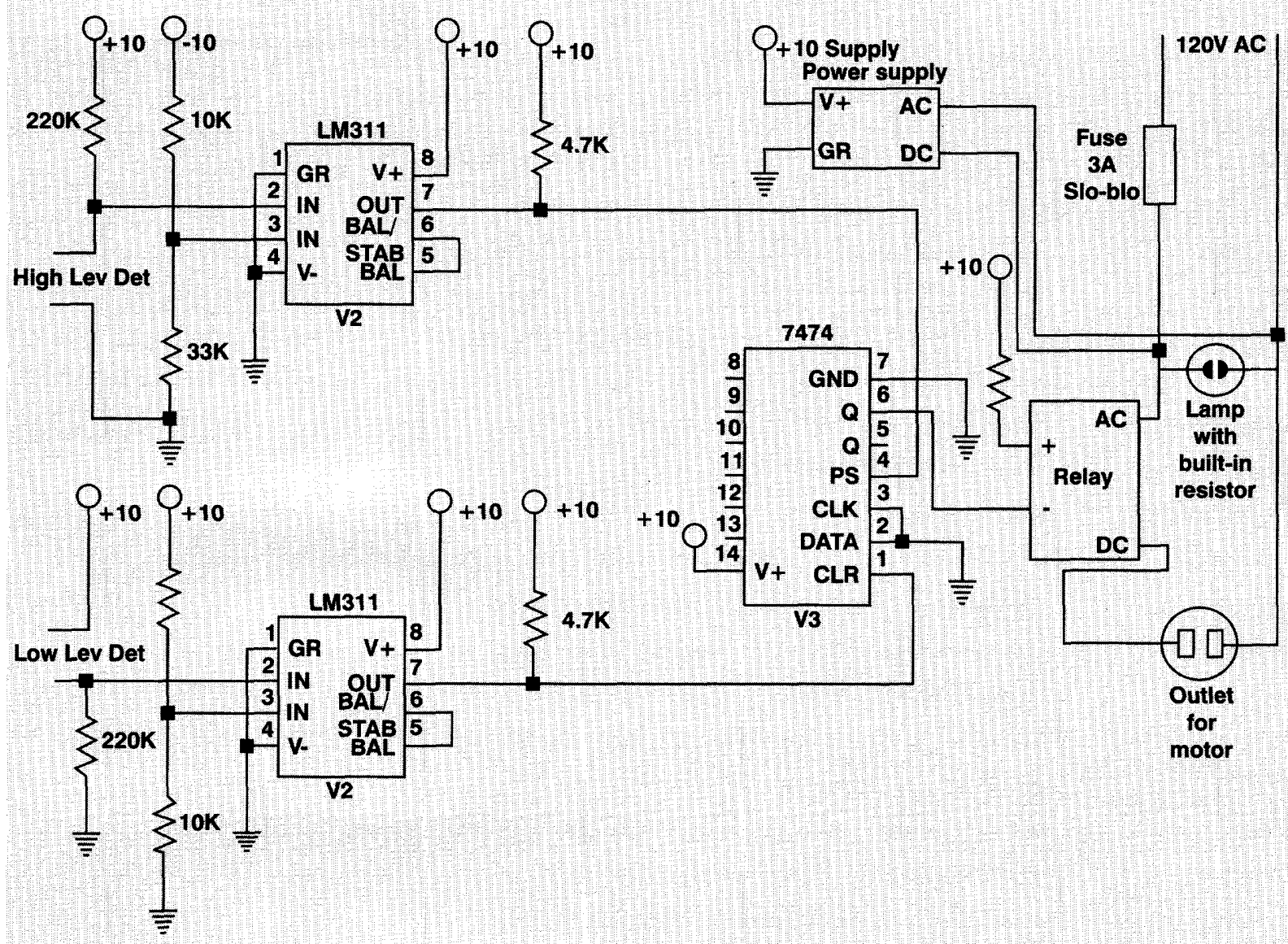

Figure 16. The circuit to control the pump from the water-level sensor in the rain sampler.

Table 8.-Sampling-site observers and their affiliation.

\begin{tabular}{ll}
\hline \multicolumn{1}{c}{ Site } & \multicolumn{1}{c}{ Name and affiliation } \\
\hline $\begin{array}{l}\text { Blue Earth } \\
\text { Camp Ripley } \\
\text { Crystal Springs }\end{array}$ & $\begin{array}{l}\text { Mary McGuire, National Atmospheric Deposition Program } \\
\text { John Huber, Kevin Cook, and Chuck Kernler, Crystal Springs Fish Hatchery, } \\
\text { Minnesota Department of Natural Resources }\end{array}$ \\
Ely & Ed Marsolek, U.S. Forest Service \\
Icelandic State Park & Karen Duray, Icelandic State Park, N. Dak. \\
Lamberton & Tony Strasser, University of Minnesota, Southwest Experimental Station \\
Marcell & Sandy Verry and Art Elling, U.S. Forest Service \\
Park Rapids & William Alden, Hubbard County Soil and Water Conservation District \\
Princeton & Geoff Delin and Matt Landon, U.S. Geological Survey; John Lamb, University \\
of Minnesota, Soil Science & Jack Ballenger, University of Minnesota, Civil Engineering \\
Rosemount & Jeff Lee, Minneapolis Park and Recreation Board \\
Minneapolis & Paul Capel, U.S. Geological Survey \\
St. Paul &
\end{tabular}


Table 9.-Glossary of common and chemical names of the pesticides targeted in this study.

\begin{tabular}{|c|c|}
\hline Common name & Chemical name \\
\hline Acetochlor & 2-chloro-N-(ethoxymethyl)-N-(2-ethyl-6-methylphenyl)-acetamide \\
\hline Alachlor & $\begin{array}{l}\text { 2-chloro-2',6'-diethyl-N-(methoxymethyl)acetanilide/2-chloro-N-(2,6-diethylphenyl)-N- } \\
\text { (methoxymethyl)acetamide }\end{array}$ \\
\hline Atrazine & 2-chloro-4-ethylamino-6-isopropylamino-1,3,5-triazine \\
\hline Azinphos-methyl & O,O-dimethyl S-(3,4-dihydro-4-oxobenzo[d]-(1,2,3)triazin-3-ylmethyl) phosphorodithioate \\
\hline Benfluralin & N-butyl-N-ethyl-2,6-dinitro-4-trifluoro-methyl-aniline \\
\hline Butylate & S-ethyl diisobutylthiocarbamate \\
\hline Chlorothalonil & tetrachloroisophthalonitrile \\
\hline Chlorpyrifos & O,O-diethyl O-(3,5,6-trichloro-2-pyridyl) phosphorothioate \\
\hline Cyanazine & 2-((4-chloro-6-(ethylamino)-s-triazin-2-yl)amino)-methylpropionitrile \\
\hline DEA & 2-chloro-4-amino-6-isopropylamino-1,3,5-triazine \\
\hline DIA & 2-chloro-4-ethylamino-6-amino-1,3,5-triazine \\
\hline Diazinon & O,O-diethyl O-2-isopropyl-6-methylpyrimidin-4-yl phosphorothioate \\
\hline EPTC & S-ethyl dipropylthiocarbamate \\
\hline Ethalfluralin & N-ethyl-a,a,a-trifluoro-N-(2-methylallyl)-2,6-dinitro-p-toluidine \\
\hline Ethoprop & O-ethyl S,S-dipropylphosphorodithioate \\
\hline Fonofos & O-ethyl S-phenyl ethylphosphonodithioate \\
\hline Lindane & 1a,2a,3a,4a,5a,6b-hexachlorocyclohexane \\
\hline Malathion & S-1,2-bis(ethoxycarbonyl)ethyl O,O-dimethyl phosphorodithioate \\
\hline Methyl parathion & O,O-dimethyl-O-(4-nitrophenyl) phosphorothioate \\
\hline Metolachlor & 2-chloro-N-(2-ethyl-6-methylphenyl)-N-(2-methoxy-1-methylethyl) acetamide \\
\hline Metribuzin & 4-amino-6-tert-butyl-4,5-dihydro-3-methylthio-1,2,4-triazine-5-one \\
\hline Pebulate & S-propyl butylethylthiocarbamate \\
\hline Pendimethalin & N-(1-ethylpropyl)-3,4-dimethyl-2,6-dinitro-benzeneamine \\
\hline Permethrin & 3-phenxoybenzyl (IRS)-cis,trans-3-(2,2-dichlorovinyl)-2,2 dimethylcyclopropanecarboxylate \\
\hline Phorate & O,O-diethyl S-ethylthiomethyl phosphorodithioate \\
\hline Prometon & 2,4-bis(isopropylamino)-6-methoxy-s-triazine \\
\hline Propachlor & 2-chloro-N-(1-methylethyl)-N-phenylacetamide \\
\hline Propanil & 3',4'-dichloro-propionanilide \\
\hline Propazine & 2-chloro-4,6-bis(isopropylamino)-1,3,5-triazine \\
\hline Simazine & 2-chloro-4,6-bis(ethylamino)-1,3,5-triazine \\
\hline Tebuthiuron & $\mathrm{N}$-(5-(1,1-dimethyl)-1,3,4-thiadiazol 2-yl)-N,N'-dimethylurea \\
\hline Terbacil & 3-tert-butyl-5-chloro-6-methyluracil \\
\hline Terbufos & S-(((1,1-dimethylethyl)thio)methyl) O,O-diethyl phosphorodithioate \\
\hline Triallate & S-(2,3,3-trichloro-2-propenyl)bis(1-methylethyl) carbamothioate \\
\hline Trifluralin & a,a,a-trifluoro-2,6-dinitro-N,N-dipropyl-p-toluidine \\
\hline
\end{tabular}


Table 10.-Pesticides in rain near Crystal Springs, Minnesota, May through September 1993.

[Total number of samples is $15 ; \mu \mathrm{g} / \mathrm{L}$, micrograms per liter; --, not detected]

\begin{tabular}{|c|c|c|c|c|c|}
\hline Common name & Brand name & $\begin{array}{c}\text { Percent } \\
\text { detections }\end{array}$ & $\begin{array}{c}\text { Maximum } \\
\text { concentration } \\
(\mu \mathrm{g} / \mathrm{L})\end{array}$ & $\begin{array}{c}\text { Median } \\
\text { concentration } \\
(\mu \mathrm{g} / \mathrm{L})\end{array}$ & $\begin{array}{c}\text { Date of } \\
\text { maximum } \\
\text { concentration }\end{array}$ \\
\hline \multicolumn{6}{|c|}{ Herbicides } \\
\hline Alachlor & Lasso & 67 & 0.81 & 0.03 & May 25 \\
\hline Atrazine & Aatrex & 67 & .29 & .02 & July 13 \\
\hline Metolachlor & Dual & 60 & .37 & .02 & May 25 \\
\hline Triallate & Far-Go & 40 & .03 & $<.01$ & July 20 \\
\hline EPTC & Eradicane & 33 & .87 & $<.01$ & May 25 \\
\hline Ethalfluralin & Sonalan & 27 & .05 & $<.01$ & July 20 \\
\hline Cyanazine & Bladex & 20 & .11 & $<.02$ & June 1 \\
\hline Pendimethalin & Prowl & 13 & .06 & $<.01$ & June 1 \\
\hline Metribuzin & Sencor & 7 & .01 & $<.01$ & June 16 \\
\hline Propanil & Erban & 7 & .01 & $<.01$ & July 1 \\
\hline Propazine & Milogard & 7 & .01 & $<.01$ & May 25 \\
\hline Simazine & Princep & 7 & .02 & $<.01$ & July 20 \\
\hline Terbacil & Sinbar & 7 & .19 & $<.02$ & May 11 \\
\hline Trifluralin & Treflan & 7 & .03 & $<.01$ & June 1 \\
\hline Benfluralin & Benefin & 0 & $<.01$ & -- & -- \\
\hline Butylate & Sutan+ & 0 & $<.01$ & -- & -- \\
\hline Pebulate & Tillam & 0 & $<.01$ & -- & -- \\
\hline Prometon & Pramitol & 0 & $<.01$ & -- & -- \\
\hline Propachlor & Ramrod & 0 & $<.01$ & -- & -- \\
\hline Tebuthiuron & Spike & 0 & $<.01$ & -- & -- \\
\hline \multicolumn{6}{|c|}{ Insecticides } \\
\hline Methyl parathion & Penncap-M & 20 & .07 & $<.02$ & August 11 \\
\hline Ethoprop & Mocap & 13 & .03 & $<.01$ & June 16 \\
\hline Malathion & Cythion & 7 & .07 & $<.02$ & July 7 \\
\hline Azinphos-methyl & Guthion & 0 & $<.02$ & -- & - \\
\hline Chlorpyrifos & Lorsban & 0 & $<.01$ & -- & -- \\
\hline Diazinon & Diazinon & 0 & $<.01$ & -- & -- \\
\hline Lindane & Lindane & 0 & $<.02$ & -- & -- \\
\hline Permethrin & Ambush & 0 & $<.01$ & -- & -- \\
\hline Phorate & Thimet & 0 & $<.01$ & -- & -- \\
\hline Terbufos & Counter & 0 & $<.01$ & -- & -- \\
\hline
\end{tabular}


Table 11.-Pesticides in rain near Lamberton, Minnesota, May through September 1993.

[Total number of samples is $18 ; \mu \mathrm{g} / \mathrm{L}$, micrograms per liter; --, not detected]

\begin{tabular}{|c|c|c|c|c|c|}
\hline Common name & Brand name & $\begin{array}{c}\text { Percent } \\
\text { detections }\end{array}$ & $\begin{array}{c}\text { Maximum } \\
\text { concentration } \\
(\mu \mathrm{g} / \mathrm{L})\end{array}$ & $\begin{array}{c}\text { Median } \\
\text { concentration } \\
(\mu \mathrm{g} / \mathrm{L})\end{array}$ & $\begin{array}{c}\text { Date of } \\
\text { maximum } \\
\text { concentration }\end{array}$ \\
\hline \multicolumn{6}{|c|}{ Herbicides } \\
\hline Alachlor & Lasso & 94 & 12 & 0.05 & May 25 \\
\hline Atrazine & Aatrex & 89 & 1.7 & .06 & June 8 \\
\hline Metolachlor & Dual & 72 & .09 & .03 & June 8 \\
\hline Metribuzin & Sencor & 39 & .05 & .02 & July 13 \\
\hline Pendimethalin & Prowl & 39 & 1.4 & .34 & June 8 \\
\hline Propachlor & Ramrod & 39 & .28 & .03 & May 25 \\
\hline Triallate & Far-Go & 39 & .26 & .07 & July 13 \\
\hline Cyanazine & Bladex & 33 & 3.5 & $<.01$ & June 15 \\
\hline EPTC & Eradicane & 33 & 1.4 & .34 & May 25 \\
\hline Ethalfluralin & Sonalan & 33 & .07 & .03 & May 25 \\
\hline Simazine & Princep & 33 & 1.2 & .17 & May 25 \\
\hline Terbacil & Sinbar & 28 & 1.4 & .06 & May 18 \\
\hline Propazine & Milogard & 17 & .05 & .05 & June 8 \\
\hline Propanil & Erban & 11 & .02 & .02 & July 27 \\
\hline Trifluralin & Treflan & 11 & .04 & .02 & June 15 \\
\hline Prometon & Pramitol & 11 & .06 & .03 & June 22 \\
\hline Butylate & Sutan+ & 6 & .03 & $<.01$ & June 8 \\
\hline Benfluralin & Benefin & 0 & $<.01$ & -- & -- \\
\hline Pebulate & Tillam & 0 & $<.01$ & -- & -- \\
\hline Tebuthiuron & Spike & 0 & $<.01$ & -- & -- \\
\hline \multicolumn{6}{|c|}{ Insecticides } \\
\hline Methyl parathion & Penncap-M & 44 & .10 & .05 & June 22 \\
\hline Terbufos & Counter & 22 & .05 & .02 & June 22 \\
\hline Chlorpyrifos & Lorsban & 17 & .08 & $<.01$ & June 8 \\
\hline Malathion & Cythion & 17 & .07 & .03 & September 28 \\
\hline Phorate & Thimet & 6 & .01 & $<.01$ & July 13 \\
\hline Azinphos-methyl & Guthion & 0 & $<.02$ & -- & -- \\
\hline Diazinon & Diazinon & 0 & $<.01$ & -- & -- \\
\hline Ethoprop & Mocap & 0 & $<.01$ & -- & -- \\
\hline Lindane & Lindane & 0 & $<.02$ & -- & -- \\
\hline Permethrin & Ambush & 0 & $<.01$ & -- & -- \\
\hline
\end{tabular}


Table 12.-Pesticides in rain, Minneapolis, Minnesota, April through September 1993.

[Total number of samples is $24 ; \mu \mathrm{g} / \mathrm{L}$, micrograms per liter; --, not detected]

\begin{tabular}{|c|c|c|c|c|c|}
\hline Common name & Brand name & $\begin{array}{l}\text { Percent } \\
\text { detections }\end{array}$ & $\begin{array}{c}\text { Maximum } \\
\text { concentration } \\
(\mu \mathrm{g} / \mathrm{L})\end{array}$ & $\begin{array}{c}\text { Median } \\
\text { concentration } \\
(\mu \mathrm{g} / \mathrm{L})\end{array}$ & $\begin{array}{c}\text { Date of } \\
\text { maximum } \\
\text { concentration }\end{array}$ \\
\hline \multicolumn{6}{|c|}{ Herbicides } \\
\hline Atrazine & Aatrex & 75 & 2.3 & .05 & June 29 \\
\hline Metribuzin & Sencor & 58 & .03 & .01 & August 10 \\
\hline Alachlor & Lasso & 54 & .98 & .01 & May 25 \\
\hline EPTC & Eradicane & 54 & .46 & .01 & May 25 \\
\hline Metolachlor & Dual & 46 & .42 & $<.01$ & June 15 \\
\hline Cyanazine & Bladex & 42 & .33 & $<.02$ & June 1 \\
\hline Pendimethalin & Prowl & 33 & .18 & $<.01$ & June 8 \\
\hline Propachlor & Ramrod & 29 & .32 & $<.01$ & May 25 \\
\hline Simazine & Princep & 25 & .46 & $<.01$ & April 8 \\
\hline Propazine & Milogard & 17 & .03 & $<.01$ & June 29 \\
\hline Tebuthiuron & Spike & 4 & .01 & $<.01$ & April 8 \\
\hline Benfluralin & Benefin & 0 & $<.01$ & -- & -- \\
\hline Butylate & Sutan+ & 0 & $<.01$ & -- & -- \\
\hline Ethalfluralin & Sonalan & 0 & $<.01$ & -- & -- \\
\hline Pebulate & Tillam & 0 & $<.01$ & -- & -- \\
\hline Prometon & Pramitol & 0 & $<.01$ & -- & -- \\
\hline Propanil & Erban & 0 & $<.01$ & -- & - \\
\hline Terbacil & Sinbar & 0 & $<.02$ & -- & -- \\
\hline Triallate & Far-Go & 0 & $<.01$ & -- & -- \\
\hline Trifluralin & Treflan & 0 & $<.01$ & -- & -- \\
\hline \multicolumn{6}{|c|}{ Insecticides } \\
\hline Methyl parathion & Penncap-M & 38 & .10 & $<.02$ & September 14 \\
\hline Chlorpyrifos & Lorsban & 25 & .01 & $<.01$ & August 4 \\
\hline Terbufos & Counter & 21 & .08 & $<.01$ & April 8 \\
\hline Azinphos-methyl & Guthion & 0 & $<.02$ & -- & -- \\
\hline Diazinon & Diazinon & 0 & $<.01$ & -- & -- \\
\hline Ethoprop & Mocap & 0 & $<.01$ & -- & -- \\
\hline Lindane & Lindane & 0 & $<.02$ & -- & -- \\
\hline Malathion & Cythion & 0 & $<.02$ & -- & -- \\
\hline Permethrin & Ambush & 0 & $<.01$ & -- & -- \\
\hline Phorate & Thimet & 0 & $<.01$ & -- & -- \\
\hline
\end{tabular}


Table 13.-Pesticides in rain near Park Rapids, Minnesota, May through September 1993

[Total number of samples is $15 ; \mu \mathrm{g} / \mathrm{L}$, micrograms per liter; --, not detected]

\begin{tabular}{|c|c|c|c|c|c|}
\hline Common name & Brand name & $\begin{array}{c}\text { Percent } \\
\text { detections }\end{array}$ & $\begin{array}{c}\text { Maximum } \\
\text { concentration } \\
(\mu \mathrm{g} / \mathrm{L})\end{array}$ & $\begin{array}{c}\text { Median } \\
\text { concentration } \\
(\mu \mathrm{g} / \mathrm{L})\end{array}$ & $\begin{array}{c}\text { Date of } \\
\text { maximum } \\
\text { concentration }\end{array}$ \\
\hline \multicolumn{6}{|c|}{ Herbicides } \\
\hline Alachlor & Lasso & 87 & 0.57 & 0.05 & May 25 \\
\hline Atrazine & Aatrex & 67 & .19 & .03 & June 8 \\
\hline Metolachlor & Dual & 67 & .62 & .03 & May 25 \\
\hline Ethalfluralin & Sonalan & 47 & .07 & $<.01$ & July 13 \\
\hline Metribuzin & Sencor & 40 & .05 & $<.01$ & July 13 \\
\hline EPTC & Eradicane & 33 & .04 & $<.01$ & May 25 \\
\hline Propachlor & Ramrod & 27 & .05 & $<.01$ & June 15 \\
\hline Tebuthiuron & Spike & 27 & .03 & $<.01$ & September 14 \\
\hline Cyanazine & Bladex & 20 & .26 & $<.02$ & June 8 \\
\hline Propazine & Milogard & 20 & .02 & $<.01$ & July 13 \\
\hline Triallate & Far-Go & 20 & .10 & $<.01$ & June 8 \\
\hline Pendimethalin & Prowl & 13 & .04 & $<.01$ & June 15 \\
\hline Propanil & Erban & 13 & .11 & $<.01$ & August 24 \\
\hline Simazine & Princep & 13 & .14 & $<.01$ & June 22 \\
\hline Terbacil & Sinbar & 13 & .04 & $<.02$ & September 14 \\
\hline Prometon & Pramitol & 7 & .02 & $<.01$ & August 24 \\
\hline Benfluralin & Benefin & 0 & $<.01$ & -- & - \\
\hline Butylate & Sutant & 0 & $<.01$ & -- & -- \\
\hline Pebulate & Tillam & 0 & $<.01$ & -- & -- \\
\hline Trifluralin & Treflan & 0 & $<.01$ & -- & -- \\
\hline \multicolumn{6}{|c|}{ Insecticides } \\
\hline Methyl parathion & Penncap-M & 40 & .06 & $<.02$ & August 3 \\
\hline Chlorpyrifos & Lorsban & 20 & .03 & $<.01$ & May 11 \\
\hline Ethoprop & Mocap & 13 & .01 & $<.01$ & July 13 \\
\hline Terbufos & Counter & 13 & .29 & $<.01$ & June 22 \\
\hline Azinphos-methyl & Guthion & 0 & $<.02$ & -- & -- \\
\hline Diazinon & Diazinon & 0 & $<.01$ & -- & -- \\
\hline Lindane & Lindane & 0 & $<.02$ & - & -- \\
\hline Malathion & Cythion & 0 & $<.02$ & -- & -- \\
\hline Permethrin & Ambush & 0 & $<.01$ & -- & -- \\
\hline Phorate & Thimet & 0 & $<.01$ & -- & -- \\
\hline
\end{tabular}


Table 14.-Pesticides in rain near Princeton, Minnesota, May through September 1993.

[Total number of samples is $10 ; \mu \mathrm{g} / \mathrm{L}$, micrograms per liter; --, not detected]

\begin{tabular}{|c|c|c|c|c|c|}
\hline Common name & Brand name & $\begin{array}{c}\text { Percent } \\
\text { detections }\end{array}$ & $\begin{array}{c}\text { Maximum } \\
\text { concentration } \\
(\mu \mathrm{g} / \mathrm{L})\end{array}$ & $\begin{array}{c}\text { Median } \\
\text { concentration } \\
(\mu \mathrm{g} / \mathrm{L})\end{array}$ & $\begin{array}{c}\text { Date of } \\
\text { maximum } \\
\text { concentration }\end{array}$ \\
\hline \multicolumn{6}{|c|}{ Herbicides } \\
\hline Alachlor & Lasso & 70 & 0.22 & 0.04 & June 15 \\
\hline Atrazine & Aatrex & 70 & 2.9 & .04 & June 25 \\
\hline Metolachlor & Dual & 60 & .31 & .02 & June 15 \\
\hline EPTC & Eradicane & 50 & .13 & .01 & June 15 \\
\hline Ethalfluralin & Sonalan & 50 & .08 & $<.01$ & June 25 \\
\hline Metribuzin & Sencor & 50 & .03 & $<.01$ & June 25 \\
\hline Pendimethalin & Prowl & 40 & .05 & $<.01$ & June 25 \\
\hline Cyanazine & Bladex & 30 & .29 & $<.02$ & June 15 \\
\hline Simazine & Princep & 30 & 1.3 & $<.01$ & June 15 \\
\hline Triallate & Far-Go & 30 & .06 & $<.01$ & August 5 \\
\hline Propanil & Erban & 20 & .02 & $<.01$ & June 25 \\
\hline Propazine & Milogard & 20 & .06 & $<.01$ & June 15 \\
\hline Terbacil & Sinbar & 20 & .03 & $<.02$ & August 5 \\
\hline Propachlor & Ramrod & 10 & .05 & $<.01$ & May 31 \\
\hline Trifluralin & Treflan & 10 & .03 & $<.01$ & July 14 \\
\hline Benfluralin & Benefin & 0 & $<.01$ & -- & -- \\
\hline Butylate & Sutan+ & 0 & $<.01$ & -- & -- \\
\hline Pebulate & Tillam & 0 & $<.01$ & -- & -- \\
\hline Prometon & Pramitol & 0 & $<.01$ & -- & -- \\
\hline Tebuthiuron & Spike & 0 & $<.01$ & -- & -- \\
\hline \multicolumn{6}{|c|}{ Insecticides } \\
\hline Methyl parathion & Penncap-M & 50 & .15 & .03 & June 15 \\
\hline Chlorpyrifos & Lorsban & 30 & .03 & $<.01$ & May 31 \\
\hline Terbufos & Counter & 30 & .02 & $<.01$ & June 25 \\
\hline Malathion & Cythion & 10 & .10 & $<.02$ & July 29 \\
\hline Azinphos-methyl & Guthion & 0 & $<.02$ & -- & -- \\
\hline Diazinon & Diazinon & 0 & $<.01$ & -- & -- \\
\hline Ethoprop & Mocap & 0 & $<.01$ & -- & -- \\
\hline Lindane & Lindane & 0 & $<.02$ & - & -- \\
\hline Permethrin & Ambush & 0 & $<.01$ & -- & -- \\
\hline Phorate & Thimet & 0 & $<.01$ & -- & -- \\
\hline
\end{tabular}


Table 15.-Pesticides in rain near Blue Earth, Minnesota, May through September 1994.

[Total number of samples is $9 ; \mu \mathrm{g} / \mathrm{L}$, micrograms per liter; --, not detected]

\begin{tabular}{|c|c|c|c|c|c|}
\hline Common name & Brand name & $\begin{array}{c}\text { Percent } \\
\text { detections }\end{array}$ & $\begin{array}{l}\text { Maximum } \\
\text { concentration } \\
(\mu \mathrm{g} / \mathrm{L})\end{array}$ & $\begin{array}{c}\text { Median } \\
\text { concentration } \\
(\mu \mathrm{g} / \mathrm{L})\end{array}$ & $\begin{array}{c}\text { Date of } \\
\text { maximum } \\
\text { concentration }\end{array}$ \\
\hline \multicolumn{6}{|c|}{ Herbicides } \\
\hline Alachlor & Lasso & 100 & 0.57 & 0.12 & May 3 \\
\hline Atrazine & Aatrex & 100 & 1.63 & .11 & June 22 \\
\hline Metolachlor & Dual & 78 & .42 & .04 & May 3 \\
\hline Cyanazine & Bladex & 56 & .25 & .10 & May 25 \\
\hline EPTC & Eradicane & 44 & .06 & .03 & May 3 \\
\hline Pendimethalin & Prowl & 44 & .06 & .02 & June 15 \\
\hline Metribuzin & Sencor & 44 & .04 & .02 & June 15 \\
\hline Acetochlor & Harness+ & 33 & .02 & .02 & Sep 21 \\
\hline Propachlor & Ramrod & 33 & .22 & .05 & May 3 \\
\hline Trifluralin & Treflan & 33 & .02 & .01 & June 15 \\
\hline Propazine & Milogard & 22 & .02 & .02 & June 22 \\
\hline Simazine & Princep & 11 & .12 & -- & June 8 \\
\hline Terbacil & Sinbar & 11 & .02 & -- & Sep 14 \\
\hline Propanil & Erban & 11 & .28 & -- & May 3 \\
\hline Benfluralin & Benefin & 0 & $<.01$ & - & -- \\
\hline Butylate & Sutan+ & 0 & $<.01$ & -- & -- \\
\hline Ethalfluralin & Sonalan & 0 & $<.01$ & -- & -- \\
\hline Pebulate & Tillam & 0 & $<.01$ & -- & -- \\
\hline Prometon & Pramitol & 0 & $<.01$ & -- & -- \\
\hline Tebuthiuron & Spike & 0 & $<.01$ & -- & -- \\
\hline Triallate & Far-Go & 0 & $<.01$ & -- & -- \\
\hline \multicolumn{6}{|c|}{ Insecticides } \\
\hline Methyl parathion & Penncap-M & 56 & .05 & .04 & July 13 \\
\hline Azinphos-methyl & Guthion & 22 & .03 & .03 & July 13 \\
\hline Lindane & Lindane & 22 & .04 & .03 & May 3 \\
\hline Chlorpyrifos & Lorsban & 11 & .02 & -- & May 3 \\
\hline Fonofos & Dyfonate & 11 & .02 & -- & June 22 \\
\hline Malathion & Cythion & 0 & $<.02$ & -- & June 15 \\
\hline Diazinon & Diazinon & 0 & $<.01$ & -- & -- \\
\hline Ethoprop & Mocap & 0 & $<.02$ & -- & -- \\
\hline Permethrin & Ambush & 0 & $<.01$ & -- & -- \\
\hline Phorate & Thimet & 0 & $<.01$ & -- & -- \\
\hline Terbufos & Counter & 0 & $<.01$ & -- & -- \\
\hline
\end{tabular}


Table 16.-Pesticides in rain near Crystal Springs, Minnesota, April through September 1994.

[Total number of samples is $22 ; \mu \mathrm{g} / \mathrm{L}$, micrograms per liter; --, not detected]

\begin{tabular}{|c|c|c|c|c|c|}
\hline Common name & Brand name & $\begin{array}{c}\text { Percent } \\
\text { detections }\end{array}$ & $\begin{array}{c}\text { Maximum } \\
\text { concentration } \\
(\mu \mathrm{g} / \mathrm{L})\end{array}$ & $\begin{array}{c}\text { Median } \\
\text { concentration } \\
(\mu \mathrm{g} / \mathrm{L})\end{array}$ & $\begin{array}{c}\text { Date of } \\
\text { maximum } \\
\text { concentration }\end{array}$ \\
\hline \multicolumn{6}{|c|}{ Herbicides } \\
\hline Atrazine & Aatrex & 86 & 1.3 & 0.11 & May 31 \\
\hline Alachlor & Lasso & 82 & .70 & .08 & May 17 \\
\hline Cyanazine & Bladex & 73 & 3.2 & .10 & May 31 \\
\hline Metolachlor & Dual & 50 & .56 & .03 & May 17 \\
\hline Metribuzin & Sencor & 50 & .25 & .02 & August 2 \\
\hline Acetochlor & Harness & 32 & .46 & .04 & April 26 \\
\hline Pendimethalin & Prowl & 32 & .07 & .04 & May 31 \\
\hline Propazine & Milogard & 27 & .02 & .02 & July 19 \\
\hline EPTC & Eradicane & 18 & .04 & .02 & May 10 \\
\hline Ethalfluralin & Sonalan & 18 & .04 & .03 & July 25 \\
\hline Propachlor & Ramrod & 18 & .02 & .02 & May 17 \\
\hline Simazine & Princep & 18 & .01 & .01 & August 2 \\
\hline Prometon & Pramitol & 14 & .02 & .01 & September 20 \\
\hline Butylate & Sutan+ & 9 & .02 & .02 & October 4 \\
\hline Pebulate & Tillam & 9 & .02 & .02 & June 14 \\
\hline Terbacil & Sinbar & 5 & .03 & -- & September 20 \\
\hline Benfluralin & Benefin & 0 & $<.01$ & -- & -- \\
\hline Propanil & Erban & 0 & $<.01$ & -- & $-\sim$ \\
\hline Tebuthiuron & Spike & 0 & $<.01$ & -- & -- \\
\hline Triallate & Far-Go & 0 & $<.01$ & -- & -- \\
\hline Trifluralin & Treflan & 0 & $<.01$ & -- & -- \\
\hline \multicolumn{6}{|c|}{ Insecticides } \\
\hline Azinphos-methyl & Guthion & 55 & .85 & .07 & May 10 \\
\hline Methyl parathion & Penncap-M & 36 & .13 & .02 & June 14 \\
\hline Lindane & Lindane & 27 & .10 & .03 & August 2 \\
\hline Terbufos & Counter & 27 & .02 & .02 & May 10 \\
\hline Fonofos & Dyfonate & 23 & .04 & .02 & July 19 \\
\hline Chlorpyrifos & Lorsban & 14 & .06 & .01 & August 2 \\
\hline Permethrin & Ambush & 5 & .01 & -- & June 28 \\
\hline Malathion & Cythion & 0 & $<.02$ & -- & May 17 \\
\hline Diazinon & Diazinon & 0 & $<.01$ & -- & -- \\
\hline Ethoprop & Mocap & 0 & $<.01$ & - & -- \\
\hline Phorate & Thimet & 0 & $<.01$ & -- & -. \\
\hline
\end{tabular}


Table 17.-Pesticides in rain near Lamberton, Minnesota, April through September 1994.

[Total number of samples is $19 ; \mu \mathrm{g} / \mathrm{L}$, micrograms per liter; --, not detected]

\begin{tabular}{|c|c|c|c|c|c|}
\hline Common name & Brand name & $\begin{array}{c}\text { Percent } \\
\text { detections }\end{array}$ & $\begin{array}{c}\text { Maximum } \\
\text { concentration } \\
(\mu \mathrm{g} / \mathrm{L})\end{array}$ & $\begin{array}{c}\text { Median } \\
\text { concentration } \\
(\mu \mathrm{g} / \mathrm{L})\end{array}$ & $\begin{array}{c}\text { Date of } \\
\text { maximum } \\
\text { concentration }\end{array}$ \\
\hline \multicolumn{6}{|c|}{ Herbicides } \\
\hline Atrazine & Aatrex & 95 & 2.8 & 0.11 & June 7 \\
\hline Alachlor & Lasso & 84 & .96 & .11 & June 7 \\
\hline Cyanazine & Bladex & 84 & 19.0 & .09 & May 24 \\
\hline Acetochlor & Harnesst & 68 & .07 & .03 & June 7 \\
\hline Metribuzin & Sencor & 68 & .13 & .04 & July 5 \\
\hline EPTC & Eradicane & 47 & .22 & .04 & April 26 \\
\hline Metolachlor & Dual & 47 & .70 & .05 & June 7 \\
\hline Propazine & Milogard & 37 & .06 & .02 & June 7 \\
\hline Pendimethalin & Prowl & 37 & .34 & .02 & June 7 \\
\hline Prometon & Pramitol & 37 & .08 & .04 & September 27 \\
\hline Simazine & Princep & 37 & .08 & .02 & July 5 \\
\hline Propachlor & Ramrod & 26 & .51 & .11 & June 7 \\
\hline Propanil & Erban & 21 & .04 & .02 & June 7 \\
\hline Trifluralin & Treflan & 21 & .21 & .03 & June 7 \\
\hline Terbacil & Sinbar & 11 & .07 & .04 & July 5 \\
\hline Ethalfluralin & Sonalan & 11 & .02 & .02 & September 27 \\
\hline Pebulate & Tillam & 11 & .03 & .02 & October 4 \\
\hline Tebuthiuron & Spike & 11 & .01 & .01 & June 14 \\
\hline Butylate & Sutant & 5 & .01 & -- & June 21 \\
\hline Benfluralin & Benefin & 0 & $<.01$ & -- & -- \\
\hline Triallate & Far-Go & 0 & $<.01$ & -- & -- \\
\hline \multicolumn{6}{|c|}{ Insecticides } \\
\hline Methyl parathion & Penncap-M & 84 & .21 & .06 & July 5 \\
\hline Azinphos-methyl & Guthion & 58 & 1.27 & .02 & July 5 \\
\hline Chlorpyrifos & Lorsban & 42 & .05 & .02 & August 9 \\
\hline Fonofos & Dyfonate & 37 & .33 & .02 & July 5 \\
\hline Terbufos & Counter & 32 & .05 & .03 & August 2 \\
\hline Lindane & Lindane & 21 & .19 & .06 & September 27 \\
\hline Malathion & Cythion & 16 & .19 & .02 & July 5 \\
\hline Permethrin & Ambush & 5 & .15 & -- & July 5 \\
\hline Diazinon & Diazinon & 0 & $<.01$ & -- & -- \\
\hline Ethoprop & Mocap & 0 & $<.01$ & -- & -- \\
\hline Phorate & Thimet & 0 & $<.01$ & -- & -- \\
\hline
\end{tabular}


Table 18.-Pesticides in rain, Minneapolis near Lake Harriet, Minnesota, April through October 1994.

[Total number of samples is $23 ; \mu \mathrm{g} / \mathrm{L}$, micrograms per liter; --, not detected]

\begin{tabular}{|c|c|c|c|c|c|}
\hline Common name & Brand name & $\begin{array}{c}\text { Percent } \\
\text { detections }\end{array}$ & $\begin{array}{c}\text { Maximum } \\
\text { concentration } \\
(\mu \mathrm{g} / \mathrm{L})\end{array}$ & $\begin{array}{c}\text { Median } \\
\text { concentration } \\
(\mu \mathrm{g} / \mathrm{L})\end{array}$ & $\begin{array}{c}\text { Date of } \\
\text { maximum } \\
\text { concentration }\end{array}$ \\
\hline \multicolumn{6}{|c|}{ Herbicides } \\
\hline Atrazine & Aatrex & 96 & 0.74 & 0.20 & July 5 \\
\hline Alachlor & Lasso & 87 & .53 & .13 & May 17 \\
\hline Metribuzin & Sencor & 74 & 1.1 & .02 & June 14 \\
\hline Cyanazine & Bladex & 61 & 6.2 & .06 & May 17 \\
\hline Metolachlor & Dual & 39 & .38 & .09 & May 17 \\
\hline EPTC & Eradicane & 35 & .10 & .03 & June 14 \\
\hline Pendimethalin & Prowl & 35 & .19 & .02 & May 17 \\
\hline Simazine & Princep & 26 & .02 & .01 & June 14 \\
\hline Propachlor & Ramrod & 22 & .13 & .07 & May 3 \\
\hline Acetochlor & Harness+ & 17 & .03 & .01 & May 17 \\
\hline Propazine & Milogard & 13 & .02 & .02 & April 26 \\
\hline Ethalfluralin & Sonalan & 4 & .08 & -- & April 26 \\
\hline Prometon & Pramitol & 4 & .01 & -- & August 2 \\
\hline Trifluralin & Treflan & 4 & .01 & -- & June 14 \\
\hline Terbacil & Sinbar & 4 & .02 & -- & May 17 \\
\hline Benfluralin & Benefin & 0 & $<.01$ & -- & -- \\
\hline Butylate & Sutan+ & 0 & $<.01$ & -- & -- \\
\hline Pebulate & Tillam & 0 & $<.01$ & -- & - \\
\hline Propanil & Erban & 0 & $<.01$ & - & -- \\
\hline Tebuthiuron & Spike & 0 & $<.01$ & -- & -- \\
\hline Triallate & Far-Go & 0 & $<.01$ & -- & -- \\
\hline \multicolumn{6}{|c|}{ Insecticides } \\
\hline Methyl parathion & Penncap-M & 48 & .49 & .03 & June 14 \\
\hline Terbufos & Counter & 17 & .06 & .02 & April 26 \\
\hline Chlorpyrifos & Lorsban & 13 & .02 & .02 & October 25 \\
\hline Azinphos-methyl & Guthion & 9 & .17 & .10 & April 26 \\
\hline Fonofos & Dyfonate & 4 & .05 & -- & April 26 \\
\hline Permethrin & Ambush & 4 & .01 & -- & June 14 \\
\hline Phorate & Thimet & 4 & .01 & -- & April 26 \\
\hline Lindane & Lindane & 0 & $<.02$ & -- & -- \\
\hline Diazinon & Diazinon & 0 & $<.01$ & -- & -- \\
\hline Ethoprop & Mocap & 0 & $<.01$ & -- & -- \\
\hline Malathion & Cythion & 0 & $<.02$ & -- & -- \\
\hline
\end{tabular}


Table 19.--Pesticides in rain near Park Rapids, Minnesota, April through September 1994.

[Total number of samples is $17 ; \mu \mathrm{g} / \mathrm{L}$, micrograms per liter; --, not detected]

\begin{tabular}{|c|c|c|c|c|c|}
\hline Common name & Brand name & $\begin{array}{c}\text { Percent } \\
\text { detections }\end{array}$ & $\begin{array}{l}\text { Maximum } \\
\text { concentration } \\
(\mu \mathrm{g} / \mathrm{L})\end{array}$ & $\begin{array}{c}\text { Median } \\
\text { concentration } \\
(\mu \mathrm{g} / \mathrm{L})\end{array}$ & $\begin{array}{c}\text { Date of } \\
\text { maximum } \\
\text { concentration }\end{array}$ \\
\hline \multicolumn{6}{|c|}{ Herbicides } \\
\hline Atrazine & Aatrex & 94 & 1.1 & 0.13 & July 5 \\
\hline Alachlor & Lasso & 88 & .57 & .10 & August 9 \\
\hline Cyanazine & Bladex & 71 & 6.0 & .23 & May 24 \\
\hline Metribuzin & Sencor & 71 & .12 & .03 & June 14 \\
\hline Metolachlor & Dual & 47 & .58 & .05 & May 24 \\
\hline Simazine & Princep & 41 & .09 & .01 & August 9 \\
\hline EPTC & Eradicane & 35 & .05 & .03 & May 3 \\
\hline Acetochlor & Harness+ & 24 & .11 & .01 & August 9 \\
\hline Prometon & Pramitol & 24 & .08 & .04 & August 9 \\
\hline Ethalfluralin & Sonalan & 18 & .05 & .04 & May 31 \\
\hline Propazine & Milogard & 18 & .02 & .01 & August 9 \\
\hline Pendimethalin & Prowl & 12 & .02 & .01 & August 9 \\
\hline Propachlor & Ramrod & 12 & .01 & .01 & May 31 \\
\hline Pebulate & Tillam & 6 & .01 & -- & June 14 \\
\hline Propanil & Erban & 6 & .02 & -- & May 24 \\
\hline Trifluralin & Treflan & 6 & .02 & -- & June 14 \\
\hline Benfluralin & Benefin & 0 & $<.01$ & -- & -- \\
\hline Butylate & Sutan+ & 0 & $<.01$ & -- & -- \\
\hline Tebuthiuron & Spike & 0 & $<.01$ & -- & -- \\
\hline Terbacil & Sinbar & 0 & $<.02$ & -- & -- \\
\hline Triallate & Far-Go & 0 & $<.01$ & -- & -- \\
\hline \multicolumn{6}{|c|}{ Insecticides } \\
\hline Azinphos-methyl & Guthion & 53 & .38 & .08 & May 10 \\
\hline Methyl parathion & Penncap-M & 53 & .24 & .04 & June 14 \\
\hline Fonofos & Dyfonate & 35 & .04 & .01 & June 14 \\
\hline Terbufos & Counter & 29 & .03 & .01 & May 31 \\
\hline Lindane & Lindane & 24 & .15 & .08 & August 9 \\
\hline Malathion & Cythion & 18 & .04 & .02 & June 14 \\
\hline Chlorpyrifos & Lorsban & 18 & .05 & .03 & August 9 \\
\hline Diazinon & Diazinon & 0 & $<.01$ & -- & -- \\
\hline Ethoprop & Mocap & 0 & $<.01$ & -- & -- \\
\hline Permethrin & Ambush & 0 & $<.01$ & -- & -- \\
\hline Phorate & Thimet & 0 & $<.01$ & -- & -- \\
\hline
\end{tabular}


Table 20.-Pesticides in rain near Princeton, Minnesota, May through September 1994.

[Total number of samples is $17 ; \mu \mathrm{g} / \mathrm{L}$, micrograms per liter; --, not detected]

\begin{tabular}{|c|c|c|c|c|c|}
\hline Common name & Brand name & $\begin{array}{c}\text { Percent } \\
\text { detections }\end{array}$ & $\begin{array}{c}\text { Maximum } \\
\text { concentration } \\
(\mu \mathrm{g} / \mathrm{L})\end{array}$ & $\begin{array}{c}\text { Median } \\
\text { concentration } \\
(\mu \mathrm{g} / \mathrm{L})\end{array}$ & $\begin{array}{c}\text { Date of } \\
\text { maximum } \\
\text { concentration }\end{array}$ \\
\hline \multicolumn{6}{|c|}{ Herbicides } \\
\hline Alachlor & Lasso & 88 & 1.2 & 0.11 & May 24 \\
\hline Atrazine & Aatrex & 88 & 2.1 & .32 & June 7 \\
\hline Cyanazine & Bladex & 59 & 24.0 & .10 & May 24 \\
\hline Metolachlor & Dual & 59 & .39 & .03 & May 24 \\
\hline Metribuzin & Sencor & 53 & .10 & .04 & September 14 \\
\hline Acetochlor & Harness+ & 41 & .14 & .02 & August 2 \\
\hline Propazine & Milogard & 41 & .03 & .02 & June 7 \\
\hline EPTC & Eradicane & 35 & .26 & .08 & July 26 \\
\hline Pendimethalin & Prowl & 35 & .43 & .12 & May 3 \\
\hline Prometon & Pramitol & 29 & .07 & .04 & July 5 \\
\hline Simazine & Princep & 29 & .04 & .02 & May 24 \\
\hline Ethalfluralin & Sonalan & 24 & .13 & .05 & May 24 \\
\hline Propachlor & Ramrod & 18 & .14 & .10 & May 16 \\
\hline Propanil & Erban & 18 & .12 & .08 & May 24 \\
\hline Terbacil & Sinbar & 12 & .03 & .02 & June 14 \\
\hline Pebulate & Tillam & 6 & .01 & -- & June 14 \\
\hline Triallate & Far-Go & 6 & .02 & -- & June 7 \\
\hline Trifluralin & Treflan & 6 & .01 & -- & May 16 \\
\hline Benfluralin & Benefin & 0 & $<.01$ & -- & -- \\
\hline Butylate & Sutan+ & 0 & $<.01$ & -- & -- \\
\hline Tebuthiuron & Spike & 0 & $<.01$ & -- & -- \\
\hline \multicolumn{6}{|c|}{ Insecticides } \\
\hline Azinphos-methyl & Guthion & 53 & .49 & .06 & May 24 \\
\hline Chlorpyrifos & Lorsban & 35 & .05 & .01 & July 26 \\
\hline Methyl parathion & Penncap-M & 35 & .18 & .11 & August 2 \\
\hline Terbufos & Counter & 29 & 1.14 & .03 & May 3 \\
\hline Phorate & Thimet & 18 & .03 & .02 & May 24 \\
\hline Fonofos & Dyfonate & 12 & .04 & .04 & July 26 \\
\hline Lindane & Lindane & 12 & .09 & .05 & August 2 \\
\hline Malathion & Cythion & 12 & .04 & .03 & May 24 \\
\hline Diazinon & Diazinon & 0 & $<.01$ & -- & -- \\
\hline Ethoprop & Mocap & 0 & $<.01$ & -- & -- \\
\hline Permethrin & Ambush & 0 & $<.01$ & -- & -- \\
\hline
\end{tabular}

